\title{
Multiple-stacked Hybrid Plays of lacustrine source rock intervals: Case studies from lacustrine basins in China
}

\author{
Shu Jiang ${ }^{1,2} \cdot$ You-Liang Feng ${ }^{3}$ Lei Chen ${ }^{4} \cdot$ Yue $\mathrm{Wu}^{5} \cdot$ Zheng-Yu Xu $^{6}$. \\ Zheng-Long Jiang ${ }^{7} \cdot$ Dong-Sheng Zhou $^{7} \cdot$ Dong-Sheng Cai $^{8} \cdot$ Elinda McKenna $^{1}$
}

Received: 11 August 2016/Published online: 27 July 2017

(c) The Author(s) 2017. This article is an open access publication

\begin{abstract}
Hydrocarbon-producing lacustrine basins are widely developed in the world, and China has a large number of lacustrine basins that have developed since the early Permian. The organic-rich shale-dominated heterogeneous source rock intervals in Chinese lacustrine basins generally contain frequent thin interbeds of stratigraphically associated sandstone, siltstone, marl, dolomite, and limestone. The concept of "Hybrid Plays" as put forth in this article recognizes this pattern of alternating organicrich shale and organic-lean interbeds and existence of mixed unconventional and conventional plays. Hybrid Plays in lacustrine source rock intervals present a unique closed petroleum system hosting continuous hydrocarbons. The interbedded organic-lean siliciclastic and/or carbonate
\end{abstract}

Shu Jiang

sjiang@egi.utah.edu

1 Energy and Geoscience Institute, University of Utah, Salt Lake City, UT 84108, USA

2 Research Institute of Unconventional Oil and Gas and Renewable Energy, China University of Petroleum (East China), Qingdao 266580, Shandong, China

3 Research Institute of Petroleum Exploration and Development, PetroChina, Beijing 100083, China

4 School of Geoscience and Technology, Southwest Petroleum University, Chengdu 610500, Sichuan, China

5 Sinopec Petroleum Exploration and Production Research Institute, Beijing 100083, China

6 PetroChina Hangzhou Institute of Geology, Hangzhou 310023, Zhejiang, China

7 School of Ocean Sciences, China University of Geosciences, Beijing 100083, China

8 CNOOC, Beijing 100027, China

Edited by Jie Hao plays are efficiently charged with hydrocarbons via short migration pathways from the adjacent organic-rich shale that is often also a self-sourced play. We assert "Hybrid Plays" provide the most realistic exploration model for targeting multiple-stacked and genetically related very tight shale, tight and conventional plays together in the entire source rock interval rather than individual plays only. The Hybrid Play model has been proven and works for a wide variety of lacustrine rift, sag and foreland basins in China.

Keywords Lacustrine basin - Hybrid Plays · Shale · Interbed $\cdot$ Source rock $\cdot$ Petroleum system

\section{Introduction}

Lacustrine shales play significant roles in providing source rock in a number of producing lacustrine basins in China, SE Asia, Brazil and Africa (Hu 1982; Kelts 1988; Katz 1990; Carroll 1998; Bohacs et al. 2000; Doust and Sumner 2007; Katz and Lin 2014). In China, lacustrine shales were deposited across a wide variety of tectonic and depositional environments both onshore and offshore since the early Permian (Huang et al. 2015; Jiang et al. 2015, 2016). Due to the relatively smaller size of lacustrine water bodies, lakes experience higher rates of environmental change compared to marine systems, resulting in small reservoir bodies characterized by rapid lateral and vertical facies changes, sensitivity to climate, broad ranges of salinity, pH, etc. (Kelts 1988; Graham et al. 1990; Lambiase 1990; Carroll and Bohacs 1999; Bohacs et al. 2000; Cohen 2003; Gierlowski-Kordesch 2010; Jiang et al. 2013a).

Chinese companies have been aggressively exploring shale gas and shale oil resources in many basins in China 
(Zhang et al. 2012a). Besides the successful development of Silurian marine Longmaxi shale gas in Sinopec's Fuling Shale Gas Field in the SE Sichuan Basin (Jiang 2014), Chinese companies have been exploring onshore unconventional hydrocarbon plays in the mature lacustrine basins of China in order to meet and maintain oil and gas production needs. Even with this dedicated effort, the lacustrine shale gas and shale oil exploration and production are moving slowly since lacustrine shales in China are clayrich, heterogeneous with a high wax content and have poor hydrocarbon flow capacity compared to marine shale (Jiang et al. 2013b, 2014, 2016; Li et al. 2013a; Jiang 2014; Katz and Lin 2014). More studies on lacustrine shale are needed to help find more realistic exploration and production models.

Naturally fractured lacustrine shales have yielded some production in China since 1960s from the Songliao and Bohai Bay Basins in NE China, the Subei Basin in East China, the Jianghan and Nanxiang Basins in Central China, the Sichuan Basin in SW China, and the Qaidam, Junggar and Turpan-Hami Basins in NW China ( $\mathrm{Li}$ et al. 2006; Zhang et al. 2014). Table 1 lists examples of production in the naturally fractured shale reservoirs of various lacustrine basins across China. The production is considered to be from the free state hydrocarbons stored in the naturally open fractures (Li et al. 2006). These shales, however, have only attracted exploration interest in the last 5 years following the shale gas success in the USA. Currently, the primary targeted tight oil/shale oil plays are listed below in age order (Wang et al. 2014):
1. Lower Permian Fengcheng tight dolomitic reservoir in the Junggar Basin and Middle Permian Lucaogou tight dolomite in the Santanghu Basin and the Jimsar depression in the Junggar Basin,

2. Upper Triassic Yanchang7 (Chang7) tight sandstone in the Ordos Basin,

3. Tight sandstone in Upper Cretaceous in the Songliao Basin,

4. Jurassic tight lacustrine carbonate in the Sichuan Basin,

5. Paleogene Shahejie Fm. in the Bohai Bay Basin,

6. Paleogene Hetaoyuan Fm. in the Biyang Basin and

7. Oligocene Shangganchaigou Fm. in the Zhahaquan area in the Qaidam Basin.

For example, the Zha7 well in the Qaidam Basin produced oil from tight sandstones in the Oligocene Shangganchaigou $\mathrm{Fm}$. at an average rate of 42 tonnes (308 barrels)/day ( 1 tonne $=7.33$ barrels); the Qiping1 well in the Songliao Basin produced oil from hydraulically fractured tight sandstone interbeds in organic-rich shale at a rate of 10 tonnes (73 barrels)/day; Lei88 well in the Liaohe Sub-basin in the Bohai Bay Basin produced oil from tight carbonates at rate of 47 tonnes (344 barrels)/day; Well in the Xi233 tight oil demonstration area in the Ordos Basin produced oil from Upper Triassic Yanchang7 (Chang7) tight sandstone at an average rate of $88+$ tonnes (645+ barrels)/day (Du et al. 2014). Due to the overwhelming focus and priority of business decisions to target shale plays, E\&P targeting thin sandstone, siltstone and

Table 1 Historical production rates from naturally fractured shales in lacustrine basins in China (compiled from Li et al. 2006; Jiu et al. 2013; Zhang et al. 2014)

\begin{tabular}{|c|c|c|c|c|}
\hline Basin & Age and Fm. & Well & Year & Average production rate per day \\
\hline $\begin{array}{l}\text { Zhanhua Sag, Bohai Bay } \\
\text { Basin }\end{array}$ & Paleogene Shahejie3 shale & He54 & 1973 & $\begin{array}{l}\text { Oil: } 91.4 \text { tonnes (670 barrels) } \\
\text { Gas: } 2740 \mathrm{~m}^{3}\left(95,900 \mathrm{ft}^{3}\right)\end{array}$ \\
\hline $\begin{array}{l}\text { Zhanhua Sag, Bohai Bay } \\
\text { Basin }\end{array}$ & Paleogene Shahejie3 shale & Luo42 & 1990 & $\begin{array}{l}\text { Oil: } 79.7 \text { tonne (584 barrels) and } \\
\text { Gas: } 7746 \mathrm{~m}^{3}\left(271,110 \mathrm{ft}^{3}\right)\end{array}$ \\
\hline $\begin{array}{l}\text { Liaohe Sub-basin, Bohai } \\
\text { Bay Basin }\end{array}$ & Paleogene Shahejie3 shale & Shugu165 & 2011 & Oil: 21 tonnes (154 barrels) \\
\hline $\begin{array}{l}\text { Dongpu Sub-basin, } \\
\text { Bohai Bay Basin }\end{array}$ & Paleogene Shahejie3 shale & Pushen-18-1 & 2011 & Oil: 370 tonnes (2712 barrels) \\
\hline $\begin{array}{l}\text { Biyang Sub-Basin, } \\
\text { Nanxiang Basin }\end{array}$ & Paleogene Hetaoyuan 3 shale & $\begin{array}{l}\text { Biye HF-1 well } \\
\text { (Horizontal well) }\end{array}$ & 2011 & Oil: 20.8 tonnes (152 barrels) \\
\hline Songliao Basin & $\begin{array}{l}\text { Upper Cretaceous } \\
\text { Qingshankou shale }\end{array}$ & $\begin{array}{l}\text { Xin19-11 well and } \\
\text { Ying12 well }\end{array}$ & & $\begin{array}{l}\text { Oil: } 26.4-35.2 \text { tonnes (194-258 barrels) for } \\
\text { well Xin } 19-11 \text { and } 4 \text { tonnes ( } 29 \text { barrels) } \\
\text { for Ying12 }\end{array}$ \\
\hline Jianghan Basin & Paleogene Qian3 shale & Wang4-12-2 & 1989 & Oil: 49.3 tonnes ( 361 barrels) \\
\hline East Sichuan Basin & Jurassic Dongyuemiao shale & Jian111 & 2010 & Gas: $3925 \mathrm{~m}^{3}\left(137,375 \mathrm{ft}^{3}\right)$ \\
\hline NE Sichuan Basin & Jurassic Dongyuemiao shale & Yuanba9 & 2010 & Gas: $11,500 \mathrm{~m}^{3}\left(402,500 \mathrm{ft}^{3}\right)$ \\
\hline
\end{tabular}


carbonate interbeds within lacustrine shales seems to have been ignored previously, just as the shale plays were historically ignored in the tight sandstone oil and gas play exploration focus areas. Our recent detailed investigation of shale gas and shale oil plays in China found that the source rock intervals in China's lacustrine basins are highly heterogeneous, having dominantly organic-rich shale source rock with thin interbeds of organic-lean siltstone, sandstone and carbonates (Jiang et al. 2015, 2016). For the most part, these thin zones within the source rock interval received only minor attention in the past since hydrocarbons do not flow without stimulation.

Sporadic reports of the production of shale oil, shale gas, tight oil, and tight gas have not closed the knowledge gap that continues to exist between naturally fractured shale reservoirs, self-sourced shale reservoirs and coarse-grained interbed intervals. Previously they were separately targeted and studied during different time frames and exploration schedules as either shale plays or tight plays. The lack of systematic studies linking the organic-rich and organiclean reservoirs inhibits a full understanding of the petroleum systems of the source rock intervals. Based on the geologic characteristics of lacustrine source rock intervals and successful oil production from the self-sourced organic-rich shale, e.g., Woodford shale and organic-lean low permeability carbonates, e.g., Niobrara and Bakken, we put forth the "Hybrid Plays" concept for multiplestacked shale related plays (stratigraphically associated siliciclastic shale, siltstone, sandstone, and carbonate plays) within the lacustrine source rock intervals. The main objective of this study is to summarize the characteristics, distribution and production potential of "Hybrid Plays" of lacustrine source rocks using typical lacustrine basins in China as case studies. The studies are based on regional geologic overviews, data observations and interpretation of lithofacies, geochemistry, mineralogy, log responses and well tests, evaluation of petroleum systems for lacustrine source rock intervals, and production analysis of both organic-rich shales, and organic-lean siliciclastic and carbonate interbeds. This integrated approach will help to better characterize and understand the types of shale-related mixed resource plays and their potentials in the China lacustrine basins and stimulate further exploration and study of lacustrine basins all over the world.

\section{Concepts and methodology}

The concept of 'Hybrid Plays' presented in this paper grew out of our comprehensive review of many terms, descriptions and geological interpretations related to unconventional reservoirs in the last two decades. Historically, there have been many terms used to describe the shale-related unconventional plays, e.g., "continuous accumulation," "unconventional reservoir/play," "shale play or shale reservoir," "hybrid shale-oil resource system," "tight (oil) play," and "resource play" (see Table 2). "Continuous accumulation" was mainly used to characterize the reservoirs charged with continuous hydrocarbons, e.g., basincentered tight gas (Schmoker 1995); it does not define the types of unconventional reservoirs. "Unconventional reservoir/play" is a broadly generic term that has been used by industry for a wide range of play types including "coal bed methane (CBM)" "tight gas," "oil shale," "shale gas," "shale oil," "tight oil," "halo oil," and others (Passey et al. 2010; Clarkson and Pedersen 2011). This usage has created a certain amount of ambiguity in academia, researchers, and industry regarding the meaning of these terminologies since they are either too broad or too narrow. The definition of "shale play or shale reservoir" is a continuous fine-grained tight plays associated with organic-rich shale source rock that is also a reservoir (Curtis 2002; Bustin 2006; Passey et al. 2010). The lithologic definition of shale is a rock consisting of extremely fine-grained particles to variable amounts of silt-size particles with a wide range in mineral composition (clay, quartz, feldspar, heavy minerals, etc.) (Passey et al. 2010). "Hybrid shale-oil resource system" defines all fine-grained organic-rich and organic-lean plays as a system where hydrocarbons are produced from both organic-rich shales and juxtaposed organic-lean lithofacies (Jarvie 2012a, b). "Tight (oil) play" was used to define tight or shale reservoirs producing light oil (Clarkson and Pedersen 2011; EIA 2013); it is not clear that it refers to tight sandstone or carbonate reservoirs or include both organic-rich shale and organic-lean tight sandstone or carbonate reservoirs. "Resource play" was used describe an accumulation of hydrocarbons existing over a large area in tight reservoirs producing unconventional oil and gas via hydraulic fracturing (e.g., Sonnenberg 2014); it is too general and not clear in play types.

In recent decades, most organic-rich fine-grained tight plays, e.g., Barnett, Niobrara, Eagle Ford, and Bakken have been labeled "shale plays" and the terms of "shale oil," "tight oil," and "resource play" are often used interchangeably in public discourse (Curtis 2002; Bustin 2006; Passey et al. 2010; Jarvie 2012a; EIA 2013). In reality, the shale interval is only a subset of all low permeability finegrained tight rocks in the source rock interval, including sandstone, siltstone, carbonates and shale. For example, among the so-called "Shale Plays" in North America large variability exists for vertical and lateral lithologies, organic matter content, petrophysical properties, etc. Only the Barnett and Tuscaloosa meet the previous definition of "Shale Plays." So-called shale plays like the Bakken/ Exshaw play (USA and Canada) actually consist of key 
Table 2 Comparison between historical terms for unconventional plays

\begin{tabular}{|c|c|c|c|}
\hline Term & Source & Advantage & Disadvantage \\
\hline $\begin{array}{l}\text { Continuous } \\
\text { accumulation }\end{array}$ & Schmoker (1995) & $\begin{array}{l}\text { Emphasize the continuous } \\
\text { distribution of } \\
\text { unconventional } \\
\text { hydrocarbons }\end{array}$ & Did not define the unconventional reservoir types \\
\hline $\begin{array}{l}\text { Unconventional } \\
\text { reservoir/play }\end{array}$ & $\begin{array}{l}\text { Passey et al. (2010), Clarkson } \\
\text { and Pedersen (2011) }\end{array}$ & $\begin{array}{l}\text { Define reservoirs with tight } \\
\text { nature comparing to } \\
\text { conventional reservoirs }\end{array}$ & Too broad or too narrow \\
\hline $\begin{array}{l}\text { Shale play or } \\
\text { shale } \\
\text { reservoir }\end{array}$ & $\begin{array}{l}\text { Curtis (2002), Bustin (2006), } \\
\text { Passey et al. (2010), Jarvie } \\
\text { (2012a, b), EIA (2013) }\end{array}$ & $\begin{array}{l}\text { Define reservoirs associated } \\
\text { with organic-rich fine- } \\
\text { grained tight plays }\end{array}$ & $\begin{array}{l}\text { Confusion of self-sourced very fine-grained organic-rich } \\
\text { shale reservoir and fine-grained organic-lean facies } \\
\text { sourced from neighboring organic-rich shale }\end{array}$ \\
\hline $\begin{array}{l}\text { Hybrid shale-oil } \\
\text { resource } \\
\text { system }\end{array}$ & Jarvie $(2012 a, b)$ & $\begin{array}{l}\text { Define all fine-grained organic- } \\
\text { rich and organic-lean plays } \\
\text { as a system }\end{array}$ & $\begin{array}{l}\text { Still focused on shale and did not capture the reservoir } \\
\text { types in the source rock interval }\end{array}$ \\
\hline Tight (oil) play & $\begin{array}{l}\text { Clarkson and Petersen (2011), } \\
\text { EIA (2013) }\end{array}$ & $\begin{array}{l}\text { Tight/shale reservoirs } \\
\text { producing light oil }\end{array}$ & $\begin{array}{l}\text { Not clear, either was used to refer to tight sandstone or } \\
\text { carbonate reservoirs or include both organic-rich shale } \\
\text { and organic-lean tight sandstone or carbonate } \\
\text { reservoirs }\end{array}$ \\
\hline Resource play & Sonnenberg (2014) & $\begin{array}{l}\text { Tight reservoirs producing } \\
\text { unconventional oil and gas } \\
\text { via hydraulic fracturing }\end{array}$ & Too general and not clear in play types \\
\hline
\end{tabular}

permeable tight dolomite, siltstone and sandstone interbeds, shales, and carbonate reservoirs (LeFever 1991; Zhang et al. 2016). The Niobrara play is a low permeability chalk and self-sourced marl reservoir with continuous hydrocarbon accumulation (Sonnenberg 2011). The organic-lean interbeds interbedded within organic-rich shale are more conductive than shale in accumulating oil and gas reserves and allowing oil and gas to travel to the wellbore due to their higher porosity and permeability (Chalmers et al. 2012; Jarvie 2014).

The organic-rich lacustrine source rock intervals usually have a mixed succession of frequently interbedded shale, sandstone and/or carbonate. This interval used to be called shale due to fine-grained nature in most cases. The reality is, neither "Shale Play" or "Tight Play" and other historical terms mentioned above are not appropriate geologic terms for lacustrine petroleum systems having stacked, diverse, and rapidly changing lithofacies since they either refer to only a single lithofacies or they lump together rocks that are lithologically diverse and have different petrophysical properties in the source rock interval. We propose "Hybrid Plays" as a term to characterize all plays associated with source rock deposits in lacustrine basins. The following four characteristics define Hybrid Plays and can be used as the criteria to identify different Hybrid Plays:

1. The source rock intervals contain a mixed succession of genetically and stratigraphically associated organicrich shale and organic-lean sandstone, siltstone and/or carbonate occurring within distinct geographical areas.
The organic-lean sandstone, siltstone, and/or carbonate are usually sandwiched between or juxtaposed against mature shale source rock.

2. Reservoirs include three end members of conventional reservoirs with high inorganic porosity and Darcy range permeability, tight reservoirs with low microdarcy range permeability, and very tight fine-grained shale reservoirs with low permeability and low inorganic and organic porosity.

3. Unlike conventional reservoirs, the petroleum accumulations in "Hybrid Plays" are not formed primarily through buoyancy. Instead, oil and gas were either generated and trapped in the source rock as in situ hydrocarbon or have efficiently migrated into fine- to coarse-grained siltstone and sandstone directly adjacent to the source rocks (Raji et al. 2015). Such hybrid conventional-tight-very tight resource plays are basically a closed petroleum system containing the oil and gas originating from organic-rich shale and is now stored within the source rock stratigraphic interval. The considerable hydrocarbon retention hosted in "Hybrid Plays" is expected to mimic the overall characteristics of continuous accumulation as defined by Schmoker (1995).

4. Horizontal drilling and hydraulic fracturing are needed to release and produce the hydrocarbons from Hybrid Plays.

The methodology in this paper follows the approach from conceptual hypothesis, observation, data description, 
data integration, interpretation, and then to validation. (1) The concept of "Hybrid Plays" was proposed based on a paucity of scientific appreciation for the play types and experience and observations with lacustrine systems. (2) Extensive literature reviews, geologic evaluation, and analysis were conducted of unconventional petroleum systems in typical lacustrine basins in China. (3) The reservoirs were evaluated to identify all the proven and potential Hybrid Plays in the source rock intervals of lacustrine basins in China using the criteria of "Hybrid Plays" based on well $\log$ data, lithology, facies, geochemistry, porosity and permeability, mineralogy, petrology, hydrocarbon shows and well test data. (4) Properties and models of "Hybrid Plays" in different types of lacustrine basins are summarized.

\section{Geology of source rocks of lacustrine basins in China}

China has a series of widely distributed lacustrine basins ranging in age from early Permian to Quaternary. During the late Paleozoic (early Permian) after the Hercynian Orogeny, lacustrine foreland basins started to develop in northwest China, e.g., the Junggar and Turpan-Hami basins (Wang and Mo 1995; Wang and Li 2004; Zou et al. 2010; Figs. 1, 2). Beginning in the Mesozoic, the continent of Asia experienced a period of intracontinental tectonic events when Indosinian, Yanshanian and Himalayan orogenies were the predominant forces shaping the landmass in China (Wang et al. 2005). The sea retreated in most regions during this time and the dominant depositional systems were marked by a preponderance of fluvial-lacustrine environments creating a high number of lacustrine basins throughout China (e.g., Triassic foreland Ordos Basin in North China, Jurassic foreland Junggar and Qaidam Basins in Southwest China, Sichuan Basin in Southwest China, Cretaceous Songliao sag Basin in NE China, Paleogene rift Bohai Bay, Jianghan, Nanxiang and Subei basins in East China, etc. (Figs. 1, 2). The early Permian to Quaternary organic-rich shales in China occur in more than $50 \%$ of the lacustrine basins (Wang et al. 2014). These organic-rich lacustrine shales comprise the majority of China's source rocks for three-quarters of China's oil resources and approximately one-half of the gas resources and are considered potential shale plays (Jia and Chi 2004; Zhang et al. 2008a; Zou et al. 2010, 2014; Lin et al. 2013; Jiang 2014; Fig. 2).

The rift development can be divided into pre-rift, synrift and post-rift stages according to the initiation and termination of rifting (Schlische 2003). Lacustrine basins in China with similar age and tectonic settings share comparable geological history, e.g., Cenozoic rift lacustrine basins can also be described as a succession of pre-rift, synrift, and post-rift stages, allowing them to be regionally correlated for tectonic development, sedimentary evolution, source rock and reservoir distribution (Jiang et al. 2013a, b). Source rocks have a fundamental role in controlling the petroleum systems in the lacustrine basins in China. High-quality source rocks were deposited during the stable syn-rift phase and post-rift high lake level phase (Jiang et al. 2013a, b). Characteristic rock types in source rock intervals are associated with different lacustrine basins in China due to different tectonic histories, paleoclimate and sediment supply conditions (Fig. 1):

1. Early Permian source rocks in Junggar and Santanghu basins in Northwest China are characterized by shale and carbonates developed in hypersaline settings;

2. Upper Triassic Yanchang7 (Chang7) Fm. source rock in the Ordos Basin is characterized by shale, sandstone, and siltstone deposited mainly in a freshwater lake (Zhu et al. 2004);

3. Eocene to Oligocene Shahejie shale source rock intervals are characterized by gypsum, limestone, dolomite, sandstone, marl, and shale deposited in brackish to fresh water.

In the following case studies, each primary lacustrine source rock in the major basins will be characterized in detail for their lithofacies association, reservoir and hydrocarbon accumulation, and "Hybrid Play" potential.

\section{Case studies of Hybrid Plays within source rock intervals of major lacustrine basins in China}

After nearly 70 years of exploration and production, the exploration of onshore lacustrine basins in China has become mature for conventional plays. The exploration focus in these lacustrine basins has been shifting toward individual, unconventional tight sandstones, limestones and dolomites, and recently to shale reservoirs to increase reserves and maintain production at current levels. As we mentioned in the Introduction section, the recent exploration results for unconventional petroleum systems demonstrate that many of these lacustrine basins are likely to be prospective for shale oil and shale gas in organic-rich shale and tight oil and gas from interbedded sandstone and carbonate rocks within source rock intervals. To date, little attention has been paid to advancing the study of the petroleum systems for the entire source rock interval.

This study targets typical lacustrine basins in China representing different basin types, different lithofacies associations, various salinity levels and distinct tectonic settings in order to characterize and compare potential reservoirs within source rocks and identify common 


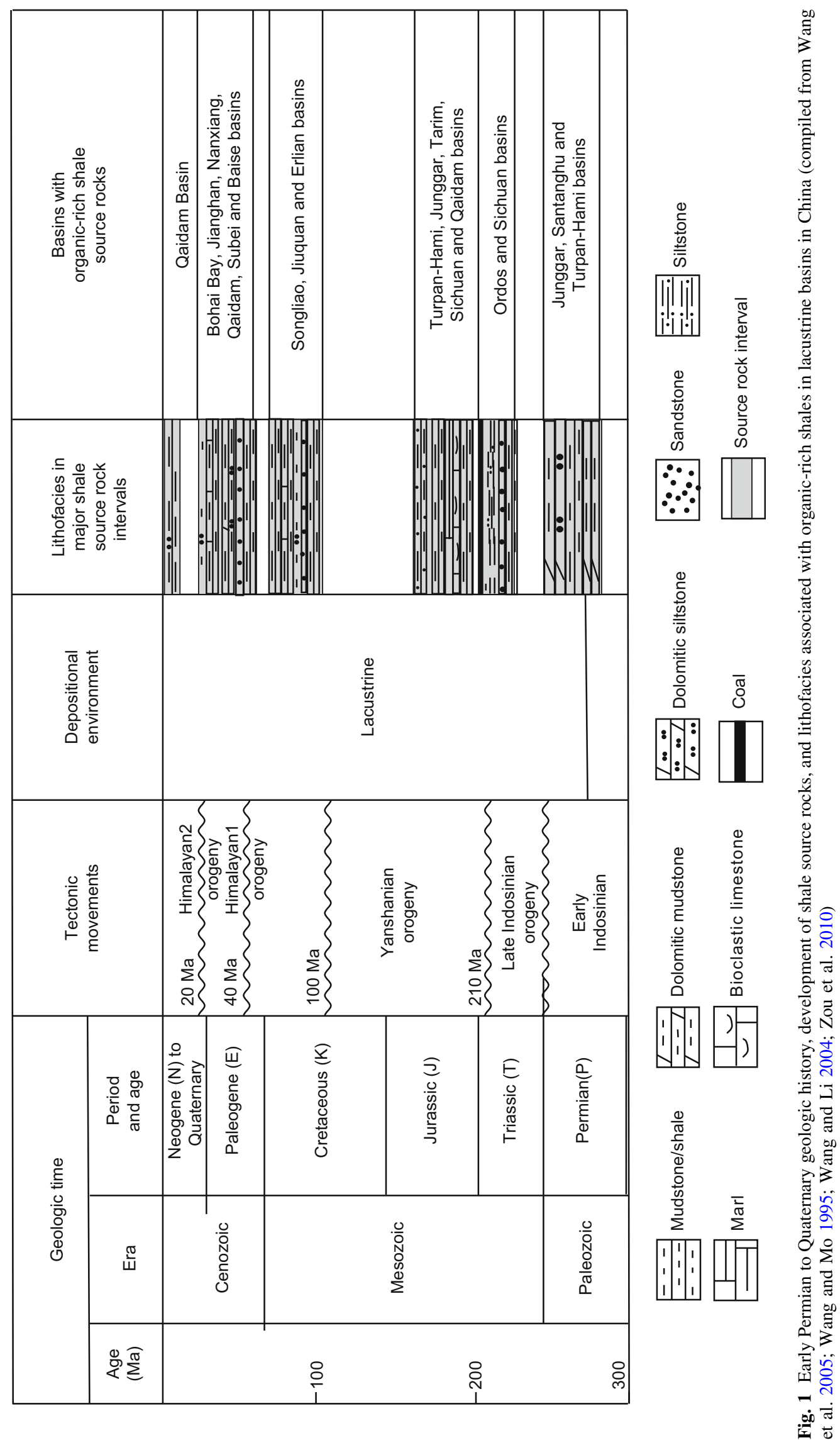




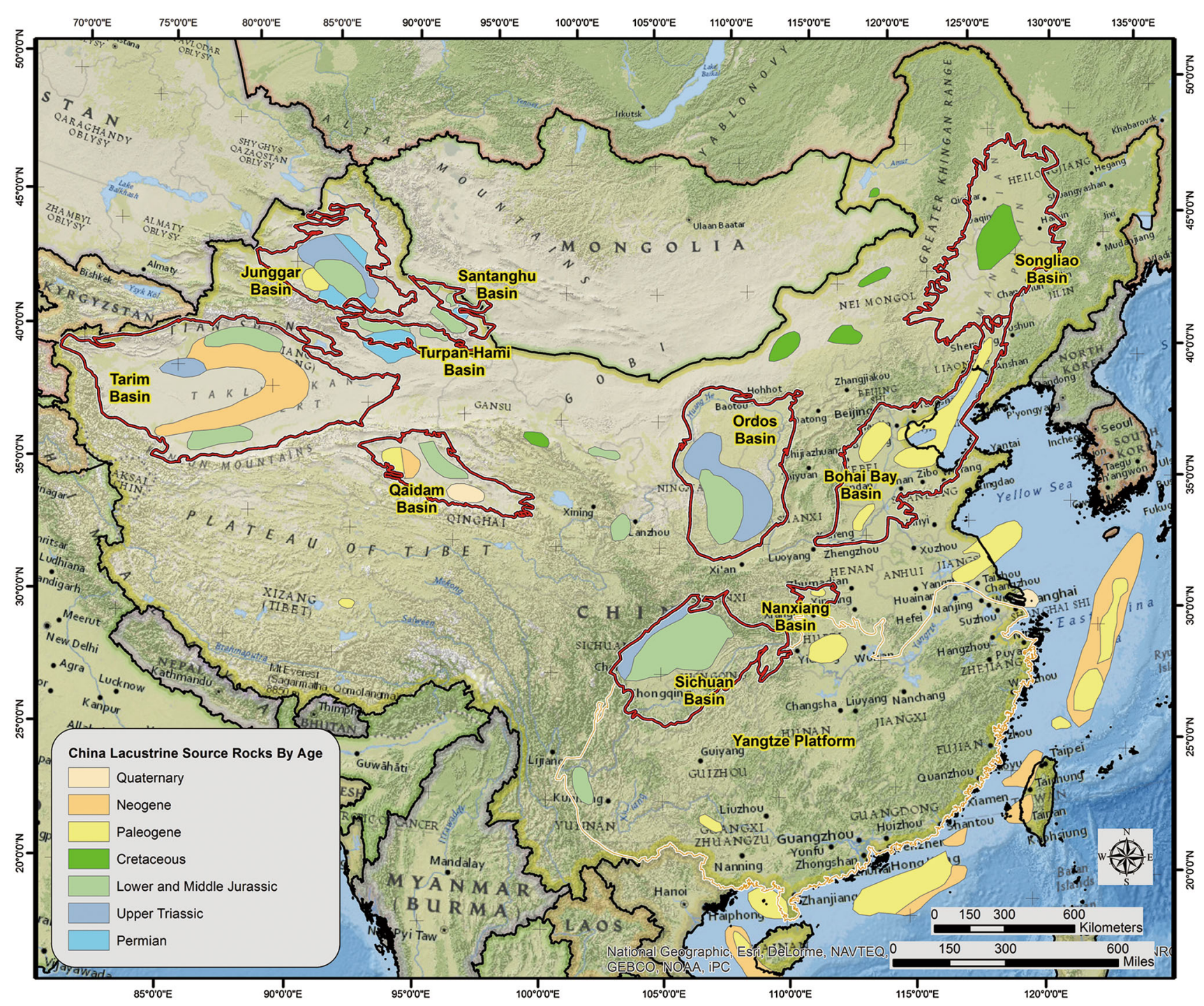

Fig. 2 Ages of the lacustrine basins in China and distribution of onshore lacustrine source rocks

"Hybrid Plays." The high-graded lacustrine basins ordered in age include:

1. Early to Middle Permian Junggar

2. Middle Permian Santanghu

3. Upper Triassic Ordos

4. Triassic to Jurassic Sichuan

5. Jurassic Turpan-Hami

6. Upper Cretaceous Songliao

7. Jurassic to Neogene Tarim

8. Paleogene Bohai Bay

9. Paleogene Nanxiang, and

10. Paleogene to Neogene Qaidam (Fig. 2).
4.1 Hybrid Plays cases within Middle Permian mixed siliciclastics and carbonate source rocks in the Junggar and Santanghu basins in Northwest China

The Junggar Basin and neighboring Santanghu and TurpanHami basins in NW China have similar geology. The Carboniferous, Permian, Triassic, and Jurassic sections all contain source rocks (Cao et al. 2005; Hao et al. 2011). Recognizing the importance of many source rock intervals including the Lower Permian Fengcheng shales (Hu et al. 2015; Xiang et al. 2015), the Middle Permian Lucaogou 
and equivalent Pingdiquan Fm. are considered the most important source rock intervals due to wide distribution, large thickness, high TOC, and good hydrocarbon potential (Carroll 1998). The Lucaogou Fm. in the Junggar and Santanghu Basins spans a wide variety of depositional environments from shallow to deep hypersaline lake. The Lucaogou Fm. consists of silty dolomite, marl, dolomitic siltstone, dolomitic shale, and shale, which are of mixed siliciclastics and carbonate. The dolomitic shale and silty dolomite were deposited in areas of low clastic supply, either in central basin areas or at basin margins starved of clastic input. We use the Jimsar Depression in the Junggar Basin and the Malang Depression in the Santanghu Basin as representatives to characterize the Hybrid Plays of Middle Permian mixed siliciclastics and carbonate source rock.

\subsubsection{Hybrid Plays within Middle Permian mixed siliciclastics and carbonate source rock in the Jimsar Depression in the Junggar Basin}

The Jimsar Depression with an area of $1500 \mathrm{~km}^{2}$ and located in the eastern portion of the Junggar Basin is a key area for current tight oil exploration targeting the Middle Permian Lucaogou Fm. The area with source rock greater than $200 \mathrm{~m}$ thick extends more than $300 \mathrm{~km}^{2}$ in the Jimsar Sag. The effective source rocks include black shale, calcareous shale, dolomitic shale, and silty shale with Type I to $\mathrm{II}_{1}$ kerogen in the Lucaogou source rock interval. Each of the source rock intervals generally have an average TOC of $>3 \%$ (up to $31 \%$ ) and an average $S_{1}+S_{2}$ of $21.0 \mathrm{mg} \mathrm{g}^{-1}$, and $R_{\mathrm{o}}$ ranging between $0.5 \%$ and $1.2 \%$. The storage types for these dolomitic reservoirs include large quantities of nanoscale to microscale interparticle pores, dissolution pores, and natural fractures. The average porosity and permeability of the tight dolomitic siltstone and silty dolomite reservoirs are about $8.8 \%$ and $0.05 \mathrm{mD}$, respectively (Kuang et al. 2012).

Exploration of structural highs of Permian dolomitic shale reservoirs in the Junggar Basin began in 1981. Since 2010, many wells have been drilled targeting dolomitic tight oil prospects (Kuang et al. 2012). Our study integrating facies mapping, geochemistry, and type well analysis indicates the "Hybrid Plays" in the Jimsar Depression include the low permeability dolomite, silty dolomite, shaly dolomite, dolomitic siltstone, organic-rich dolomitic shale, and shale in the Lucaogou source rock interval (Fig. 3a, b). Using the vertical Ji174 well as an example (Fig. 3b), the heterogeneous source rock interval consists of black to gray shale, silty shale, dolomitic shale, dolomitic siltstone, siltstone, dolomite, and limestone. Effective source rocks include black shale, calcareous shale, dolomitic shale, and silty shale with TOC ranging from $2 \%$ to
$11 \%$ (average of $4.0 \%$ ), $0.2 \%$ to $13 \%$ (average of $3.7 \%$ ), $0.77 \%$ to $7 \%$ (average of $3.3 \%$ ) and $0.4 \%$ to $10.2 \%$ (average of $3.6 \%$ ), respectively. The presence of mobile oil within the entire source rock interval is easily seen from the abundant oil stains on naturally fractured fine-grained cores and is evidenced by $T_{\max }$ of $430-460{ }^{\circ} \mathrm{C}, R_{\mathrm{O}}$ of $0.78 \%-$ $0.95 \%$ and the abundant extract of chloroform bitumen "A" in all the lithologies. The high free oil content indicated by chloroform bitumen "A" in the organic-lean dolomitic siltstone reveals that the oil migrated from juxtaposed organic-rich source rock intervals (Fig. 3b). The well was fractured targeting four zones with a gross thickness of $55 \mathrm{~m}$ in the source rock interval and oil was produced at a rate of 15 tonnes (109 barrels)/day. The production is from a "Hybrid Play" system consisting of shale, dolomitic shale, dolomitic siltstone and siltstone reservoirs (Fig. 3b). The best quality reservoir is from the dolomitic siltstone with high oil saturation $(>90 \%)$, high porosity $(12 \%-16 \%)$ and high permeability $(0.1-1 \mathrm{mD})$ compared to the organic-rich shale interval with relatively lower oil saturation $(<70 \%)$, low porosity $(<5 \%)$ and low permeability $(<0.01 \mathrm{mD})$ (Jin et al. 2015). The presence of good-quality reservoir facies (brittle dolomitic rock), welldeveloped fracture networks, mature source rock (oil window), moderate structural deformation, and thick regional cap rock make the Lucaogou a "Hybrid Play" system with continuous oil accumulation. Many recent commercial wells in the Jimsar Depression confirm this designation as a Hybrid Play system, e.g., the Lucaogou source rock interval in Ji25, Huobei2 and Fengnan7 wells reportedly produced oil from hybrid dolomitic siltstone, dolomitic shale, siltstone, and silty dolomite plays. Initial Production (IP, based on 24-h test) rates were measured at 18.16 tonnes (134 barrels)/day, 14.39 tonnes (106 bar$\mathrm{rels}$ )/day and 12.3 tonnes (91 barrels)/day, respectively, after moderate reservoir stimulation (Kuang et al. 2012). The variation in production for these wells located in different areas is attributed to the spatial heterogeneity in facies change, structural setting, source rock maturity, source rock type, reservoir type, pressure, etc.

\subsubsection{Hybrid Plays within Middle Permian mixed siliciclastics and carbonate source rock in the Malang Sag in the Santanghu Basin}

The Santanghu Basin is located to the southeast of the Junggar Basin in NW China. The key area-Malang Sagis located in the SE Santanghu Basin. Due to little terrestrial input and hypersaline depositional conditions similar to the Jimsar Depression in the Junggar Basin, the Lucaogou Fm. is mainly composed of alternating mixed siliciclastic mudstone and carbonate rocks. A localized fan delta has a limited extent in the southwestern margin of the 

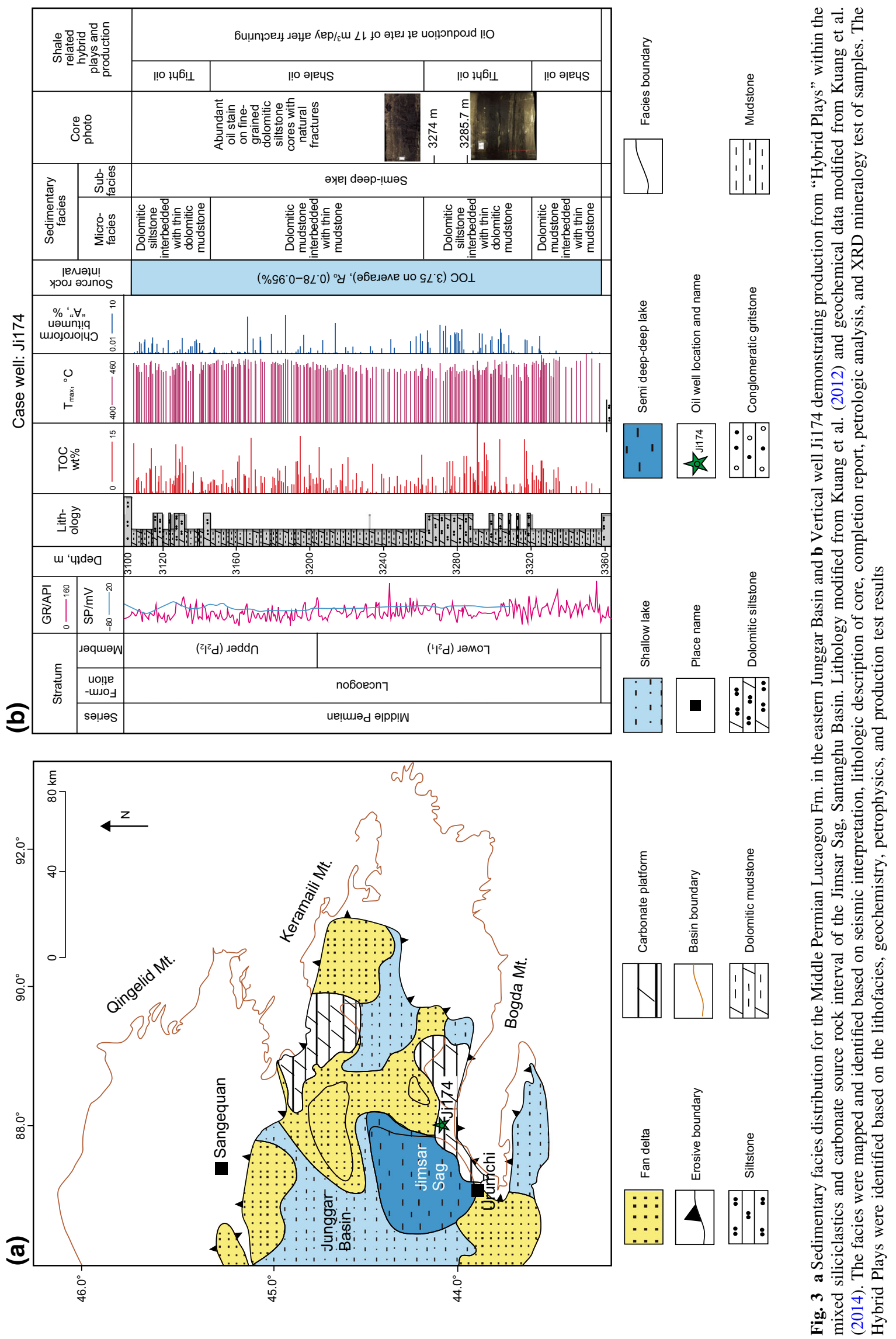
Malang sag. Volcanic rocks are mainly distributed in the Mazhong structural belt (Fig. 4a). The primary source rock is the Middle Permian Lucaogou Fm. The oil reservoirs of the Permian interval mainly consist of mudstone, dolomitic shale or limestone-rich mudstone/marl, argillaceous limestone, and calcareous dolomite within the Lucaogou Formation $\left(\mathrm{P}_{2} \mathrm{l}\right)$ source rock of the middle Permian (Liang et al. 2014), making it overall a self-sourced reservoir. The first well Ma1 was drilled in 1996 targeting interbedded intervals of fractured tight carbonates producing at a rate of 3.3 tonnes ( 24 barrels)/day. Since that discovery tight oil, exploration has been the focus in this basin. According to a variety of sources, the Malang Sag is estimated to have 1.9 billion tonnes (14 billion barrels) of tight oil resources.
Based on the vertical Ma7 well drilled and hydraulically fractured in 2004, the heterogeneous Lucaogou source rock interval is mainly composed of dolomitic mudstone, tuffaceous mudstone, and calcareous shale, making it a high-quality source rock with TOC content ranging from $1 \%$ to $7 \%$ and $R_{\mathrm{O}}$ values from $0.5 \%$ to $0.9 \%$ (Fig. $4 \mathrm{~b}$ ). This "Hybrid Play" produced oil from the source rock interval interbedded with dolomitic mudstone, tuffaceous mudstone, calcareous shale, and argillaceous limestone reservoirs at a rate of 22 tonnes (160 barrels)/day after hydraulic fracturing. For this Ma7 well, the lower member of Lucaogou Fm. consisting of dolomitic mudstone and tuffaceous mudstone is interpreted mainly as a shale oil play and the upper member of the Lucaogou Fm. consisting

(a)

$94.0^{\circ}$

$94.2^{\circ}$

$94.4^{\circ}$

(b)

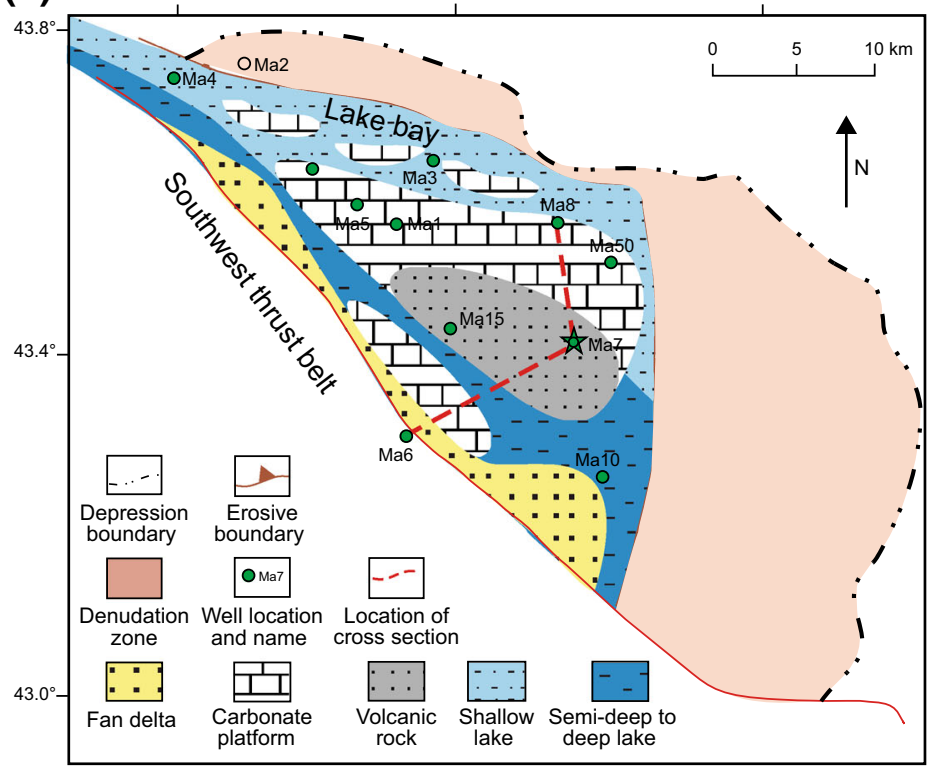

(b)

Well Ma7

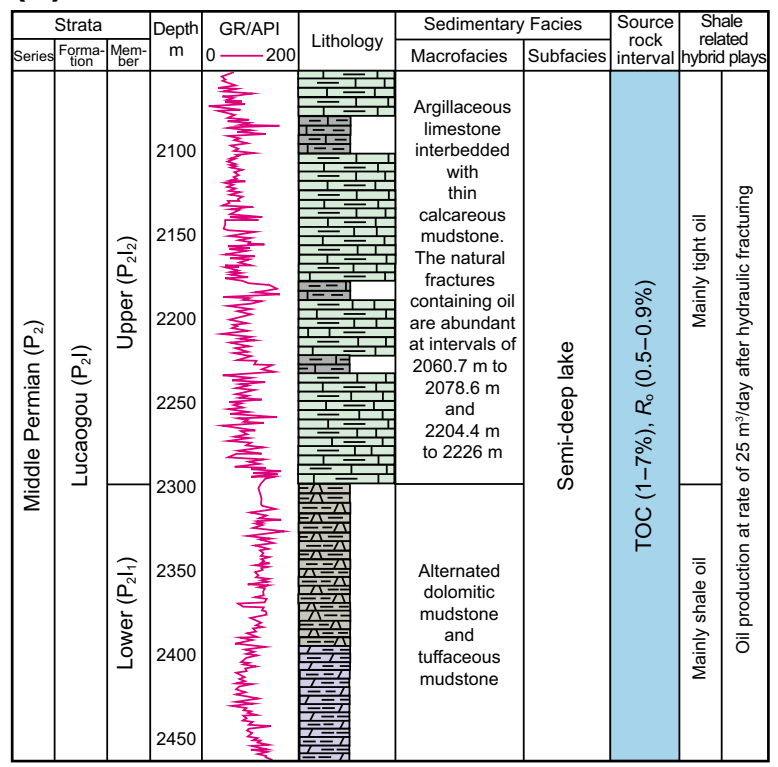

(c)
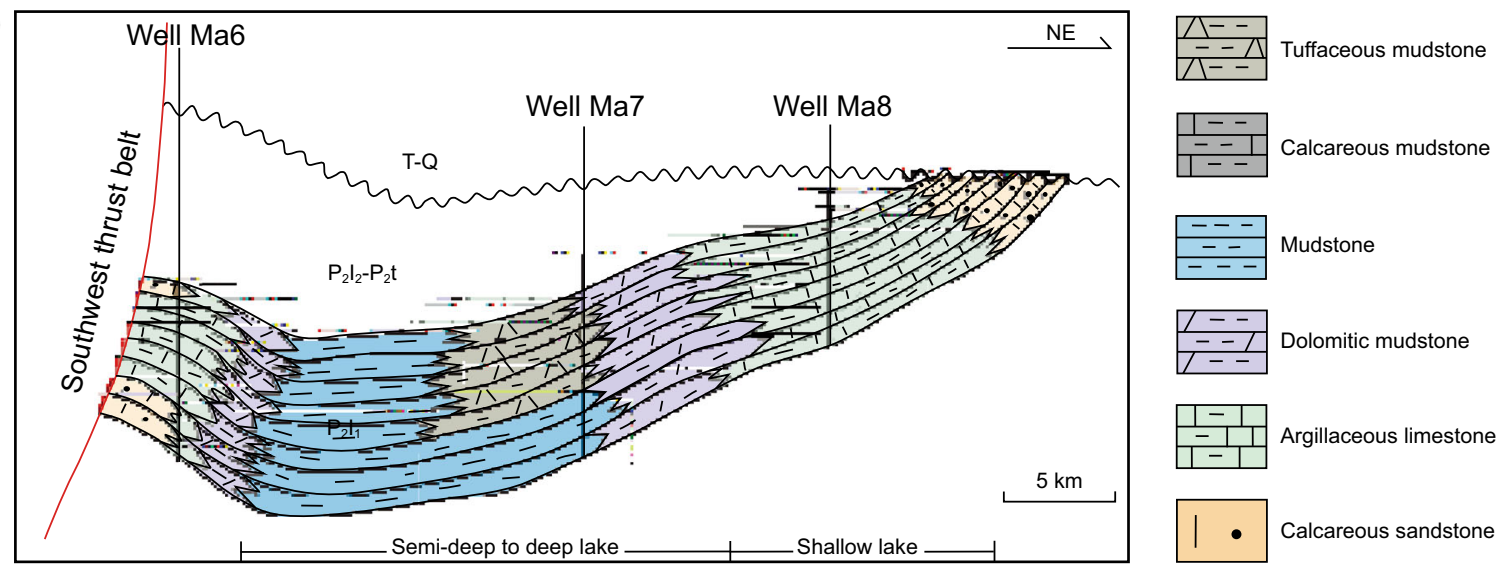

$\frac{-\Delta}{\Delta--}$ Tuffaceous mudstone
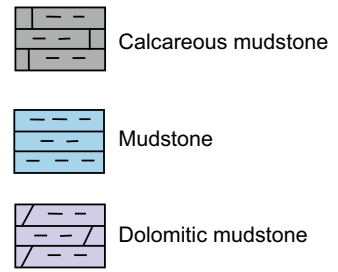

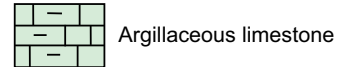

Fig. 4 a Sedimentary facies distribution for the Middle Permian Lucaogou Fm. in the Malang Sag of the Santanghu basin. b Stratigraphic column showing lithofacies, geochemistry, and drilling results of vertical Ma7 Well showing "Hybrid Plays" in the Middle Permian Lucaogou Fm. c Cross-well Ma6-Ma7-Ma8 profile illustrating spatial lithofacies variation in the Lower member of the Lucaogou
Fm. from the margin to the central sag. The facies were mapped and identified based on seismic interpretation, lithologic description of core, completion reports, petrologic analysis, and XRD mineralogy test of samples. The Hybrid Plays were identified based on the lithofacies, geochemistry, petrophysics, and production test results 
of naturally fractured argillaceous limestone interbedded with thin, organic-rich calcareous mudstone is regarded mainly as a tight oil reservoir (Fig. 4b). The regional well correlation shows that the lithofacies for the lower member of the Lucaogou Formation varies from calcareous sandstone, to argillaceous limestone, and dolomitic mudstone, and then to mudstone from the margin toward the central sag (Fig. 4c). The multiple lithofacies, continuous and regional distribution of the Lucaogou source rock interval clearly place it in the "Hybrid Play" model. Many wells (e.g., Ma58, Ma1, Ma6, Ma7, Ma8, Ma19, Ma21, Ma24) confirm the "Hybrid Play" characteristics of the Lucaogou source rock interval. The recent horizontal well and multistage hydraulic fracturing further improved the production rates and increased the economic viability. The horizontal Ma58H well produced oil at a rate of 115 tonnes (839 barrels)/day (based on an average 24-h test result) from a lateral of $804 \mathrm{~m}$ in a fractured section of the Lucaogou shale and argillaceous carbonate. Based on the drilling results, the oil is primarily produced from the tight argillaceous dolomite play with a second zone of production from the self-sourced Lucaogou dolomitic shale, calcareous shale, and limestone-rich shale/marl plays. The production is due in part to the brittle nature of the argillaceous dolomite allowing more efficient hydraulic fracturing. The marl, dolomitic shale, and calcareous shale are more ductile.

Based on the analysis of the Lucaogou source rock interval in the Junggar and Santanghu Basins, the major production of liquid hydrocarbons is from the Lucaogou dolomitic siltstone and argillaceous dolomite, which are analogous to the Bakken play in the Williston Basin in USA and Canada. The dolomite-rich mixed siliciclastics and carbonate formation is comparable to the prolific oil producing Middle Bakken mixed dolomite and siltstone.

\subsection{Hybrid Plays within Upper Triassic siliciclastic source rock in Ordos Basin}

The Ordos Basin is situated in the North China Block and is bounded by the Yin, Lüliang, Qinling, Liupan, and Helan mountains to the north, east, south, and west, respectively. The stratigraphy of the Ordos Basin records an evolution from a cratonic-passive margin basin through the Paleozoic to a Triassic intracratonic foreland basin. During late Triassic, the basin evolved into a continental setting due to the Indosinian tectonic movements (Yang et al. 2005; Hanson et al. 2007; Zou et al. 2012). No faults and folds developed in the basin and the gentle structure is a smooth monocline with an east to west dip of less than $1^{\circ}$ (He 2002).

The stratigraphy of the Yanchang Formation reveals the temporal evolution of a freshwater siliciclastic lacustrine setting based upon the lack of evaporates and carbonates.
The source rock interval is the 7 th member of the Upper Yanchang (or Chang7) shale and was deposited mainly in semi-deep to deep lake settings (Chen et al. 2007). The hot shale (TOC $>2 \%$, up to $36 \%$ and oil bearing) thickness is between 20 and $40 \mathrm{~m}$ in the semi-deep to deep lake setting in most parts of the Ordos Basin (Fig. 5a). The heterogeneous organic-rich shale source rock is usually interbedded with fine-grained, massive sandy debrite, fine-grained siltstone to sandstone turbidites, and sandy slumps (Zou et al. 2012, 2015; Liu et al. 2017; Fig. 5b, c), indicating that tight oil and shale oil potentials coexist in the Chang7 source rock interval. From the L189 well (Fig. 5), we can clearly see that organic-rich shale is mainly developed in the transgressive systems tract (TST). The test in the TST interval consisting of organic-rich shale and sandstone yielded oil of 13.2 tonnes (98 barrels)/day. The production tests are influenced by both the shale oil and tight sandstone oil plays based on perforation locations, lithofacies association, and log interpretation. The presence of shale oil accumulation is identified based on high gamma ray, high resistivity, low density, and high acoustic travel time (Fig. 5b). In the high-stand systems tract (HST), the tight sandstone is well-developed supporting the interpretation of a tight (sandstone) oil play (Fig. 5b, c). A regional stratigraphic cross section for the proven tight sandstone oil producing play further confirms the shale play potential based on overpressure inferred by residue pressure (the difference between formation pressure and hydrostatic pressure) in this organic-rich shale interval (Fig. 5d). Slight overpressure also exists in the tight sandstone oil reservoir in this area even though the Chang7 Fm. in the Ordos Basin is generally underpressured. The higher residue pressure in the organic-rich shale compared to tight sandstone indicates abundant generated oil is still trapped in the shale. At the same time, the relatively high permeability with microdarcy to millidarcy range is associated with the sandstone interval (Fig. 5d), explaining why the sandstone is a target for tight oil exploration and development. A significant portion of the generated oil from the organicrich shale migrated to the adjacent interbedded tight sandstone. The interbedded organic-rich oil-bearing shale and thin sandstone layers form "sandwich" style hydrocarbon generation, charge, and accumulation system, the hydrocarbons from the overpressured organic-rich shale migrated into and charged the sandstone interbeds very efficiently due to direct contact of shale source rock and sandstone reservoir (Ran et al. 2013). As organic-lean lithofacies are typically brittle and have the best production for shale resource plays in North America (Jarvie 2014), a similar occurrence is seen in the thin sandstones with porosity of $2 \%-12 \%$ and abundant high angle tectonic natural fractures in the lacustrine Ordos Basin. These thin sandstones are better candidates for successful hydraulic 

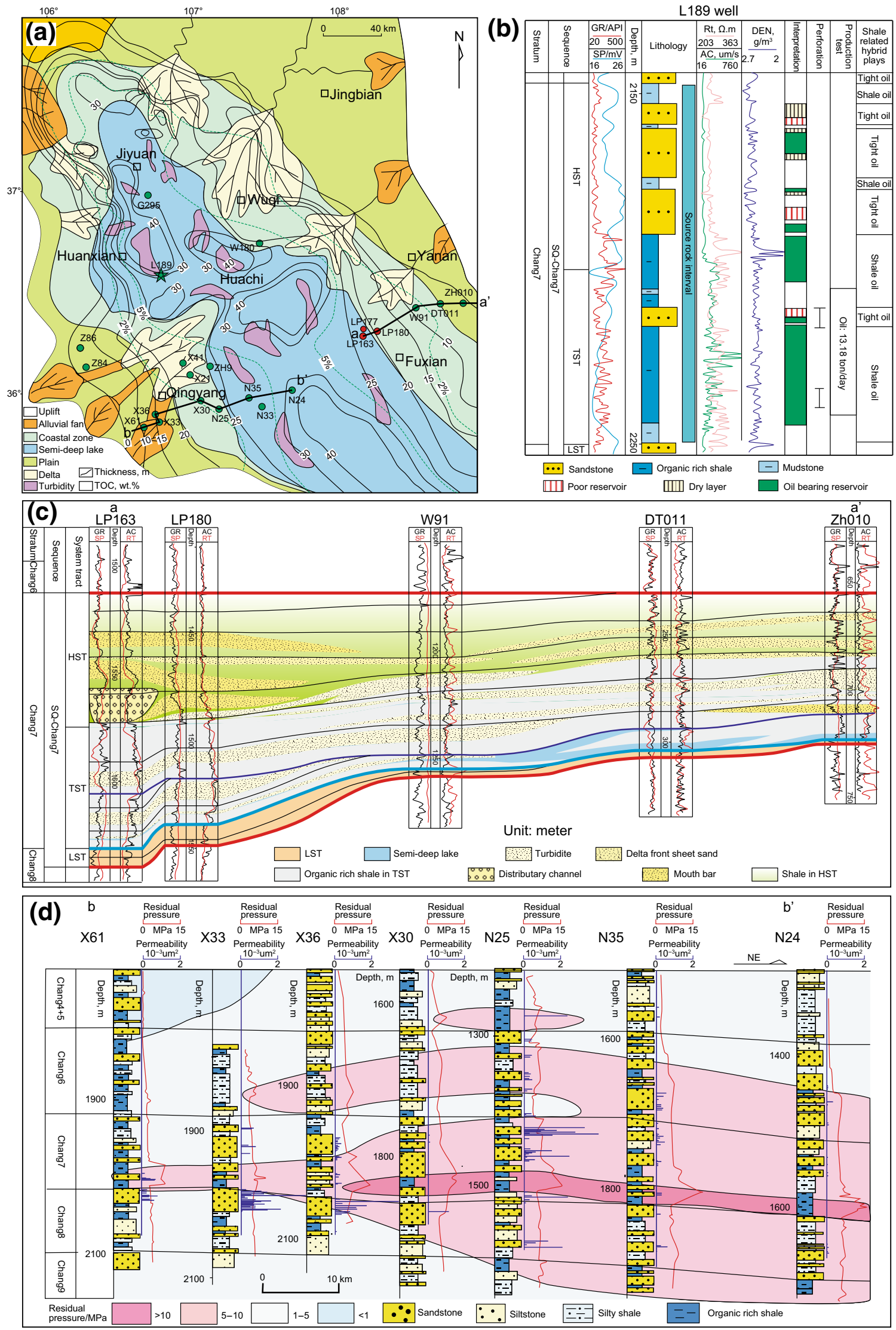
4Fig. 5 a Sedimentary facies, TOC and thickness of the organic-rich 7th Member of the Upper Triassic Yanchang Formation (Chang7) in the Ordos Basin. Thickness maps where TOC $>2 \%$ (modified from Yang et al. 2013). The green and red dots denote oil and gas production, respectively; b Properties of Chang7 source rock interval in L189 well (After Yang et al. 2013); c West-to-east cross section showing the stratigraphic variation of the Chang 7 source rock interval across the Xifeng Oilfield (Section location in a). The facies were identified based on regional facies distribution, well log characteristics, lithologic association, and well correlation; d Westto-east cross section showing the residual pressure (difference between formation pressure and hydrostatic pressure) distribution and permeability of the Chang7 source rock interval (Section location in a) (After Yao et al. 2013). The "Hybrid Plays" were identified based on the lithofacies, geochemistry, petrophysics, pressure, and production test results

fracturing and are expected to deliver hydrocarbons better than the clay-rich Chang7 shale characterized by low porosity $(<5 \%)$ and extremely low permeability (Zeng and Li 2009; Zhang et al. 2013). For the interbedded sandstone and siltstone in the Chang7 source rock, the predominantly tight sandstone and siltstone reservoirs exhibit overall low permeability (Yang et al. 2013; Yao et al. 2013). The interbedded sandstone and siltstone could be classified as conventional turbidite sandstones and siltstones, and sandy debrite reservoirs if the permeability value is higher than $0.1 \mathrm{mD}$ (Zou et al. 2012). As an example, the 10-20 m sandstone interbeds having permeability at approximately $2 \mathrm{mD}$ from the X33, X36 and N25 wells could be classified as a conventional play.

A "Hybrid Play" system for the Chang7 source rock interval has been proven by recent E\&P. Production was recorded from both organic-rich shale, and sandstone and siltstone interbeds. In 2011, Yanchang Petroleum drilled China's first lacustrine shale gas well, the vertical Liuping177 in the organic-rich shale with $R_{\mathrm{O}}>1.1 \%$ in the SE Ordos Basin (Xu and Bao 2009; Zou et al. 2010). This well confirmed the presence and potential of shale gas reservoirs in lacustrine basin sediments. The initial production (IP) of a 24-h test flowed at the rate of $2350 \mathrm{~m}^{3}\left(82,250 \mathrm{ft}^{3}\right) /$ day from the organic-rich shale interval, affirming the shale gas potential in the Ordos Basin. Several other wells drilled in this area all produced shale gas at IP up to $8000 \mathrm{~m}^{3}$ $\left(280,000 \mathrm{ft}^{3}\right) /$ day from "Hybrid Plays" with adjacent beds of shale and tight sandstone. For the sand-dominant reservoirs within the organic-rich Chang7 shale, most have thicknesses of 5-25 m, porosity of 4\%-10\% and permeability less than $0.3 \mathrm{mD}$ and are juxtaposed with the Chang7 shale source rock. The sand-rich zones have been targeted for continuous accumulation of tight oil hydrocarbons. For example, in the Zhidan area in the central west Ordos Basin, tight oil production has been tested in the sandstone interbeds within the Yanchang7 shale source rock interval with TOC content ranging from $3 \%$ to $8 \%$ in
127 wells. There are 29 wells with average oil production rates of $8.8+$ tonnes $(64+$ barrels $) /$ day. For the shale oil potential in the Ordos Basin, PetroChina Changqing Oilfield drilled and fractured the G295 well and the test result showed this well produced oil at 20.4 tonnes (150 barrels)/day from the organic-rich Yanchang7 (Chang7) shale with a thickness of $28 \mathrm{~m}$ and some natural fractures. Hybrid fracturing has been used to target the hybrid hydrocarbon-bearing organic-rich shale and organic-lean sandstone reservoirs within Yanchang7 (Chang7) source rock interval (Zhou et al. 2012).

\subsection{Hybrid Plays within Jurassic carbonate- containing source rock in the Sichuan Basin}

The Sichuan Basin is a large composite petroliferous basin located in the southwest part of China. It consists of thick Precambrian to Silurian marine shales and Triassic to Jurassic lacustrine shales. Recently, commercial shale gas production began from the Silurian Longmaxi marine shale in the Fuling Shale Gas Field located in SE Sichuan Basin (Jiang 2014; Jiang et al. 2015, 2016). Tight gas, shale gas, tight oil, and shale oil also have been sporadically produced from the Triassic Xujiahe and Jurassic Ziliujing Formations. This paper focuses on the Jurassic "Hybrid Plays" in the Sichuan Basin.

During the Early Jurassic, organic-rich shale and bioclastic shoals (mainly bioclastic or shelly limestone) were deposited in the Sichuan Basin (Fig. 6a). The Lower Jurassic Ziliujing lacustrine shale has a TOC content of $1 \%-2 \%$ (Fig. 6a). From the Yuanlu4 well in the northeast Sichuan Basin, it can be seen that gas is present in the entire Da'anzhai member source rock interval with lithologies ranging from organic-rich shale and marl, to organic-lean bioclastic limestone (Fig. 6b). This is a typical "Hybrid Play" system containing shale gas and tight carbonate gas reservoirs. A comparable trend is identified in the Jianye1HF horizontal well in the Jiannan Gas Field in the eastern Sichuan Basin. Good hydrocarbon shows (based on total hydrocarbon anomalies by mud logging) are reported in the Dongyuemiao member (Da'anzhai member equivalent) source rock interval. The lower Dongyuemiao has very good hydrocarbon shows from both organic-rich shale and organic-lean bioclastic limestone and marl. The Upper Dongyuemiao Member was hydraulically fractured and based on a 24-h performance test produced gas at rate of $12,000 \mathrm{~m}^{3}\left(420,000 \mathrm{ft}^{3}\right) /$ day from the shale and tight carbonate (marl) "Hybrid Plays" (Fig. 6c).

Currently, the lacustrine shale gas and shale oil exploration in Sichuan Basin is active in the northeast, east, and southeast regions of the basin. The vertical Yuanba21 well in the northeast produced gas at $50.7 \times 10^{4} \mathrm{~m}^{3}$ $\left(1774 \times 10^{4} \mathrm{ft}^{3}\right) /$ day from the "Hybrid Plays" consisting 


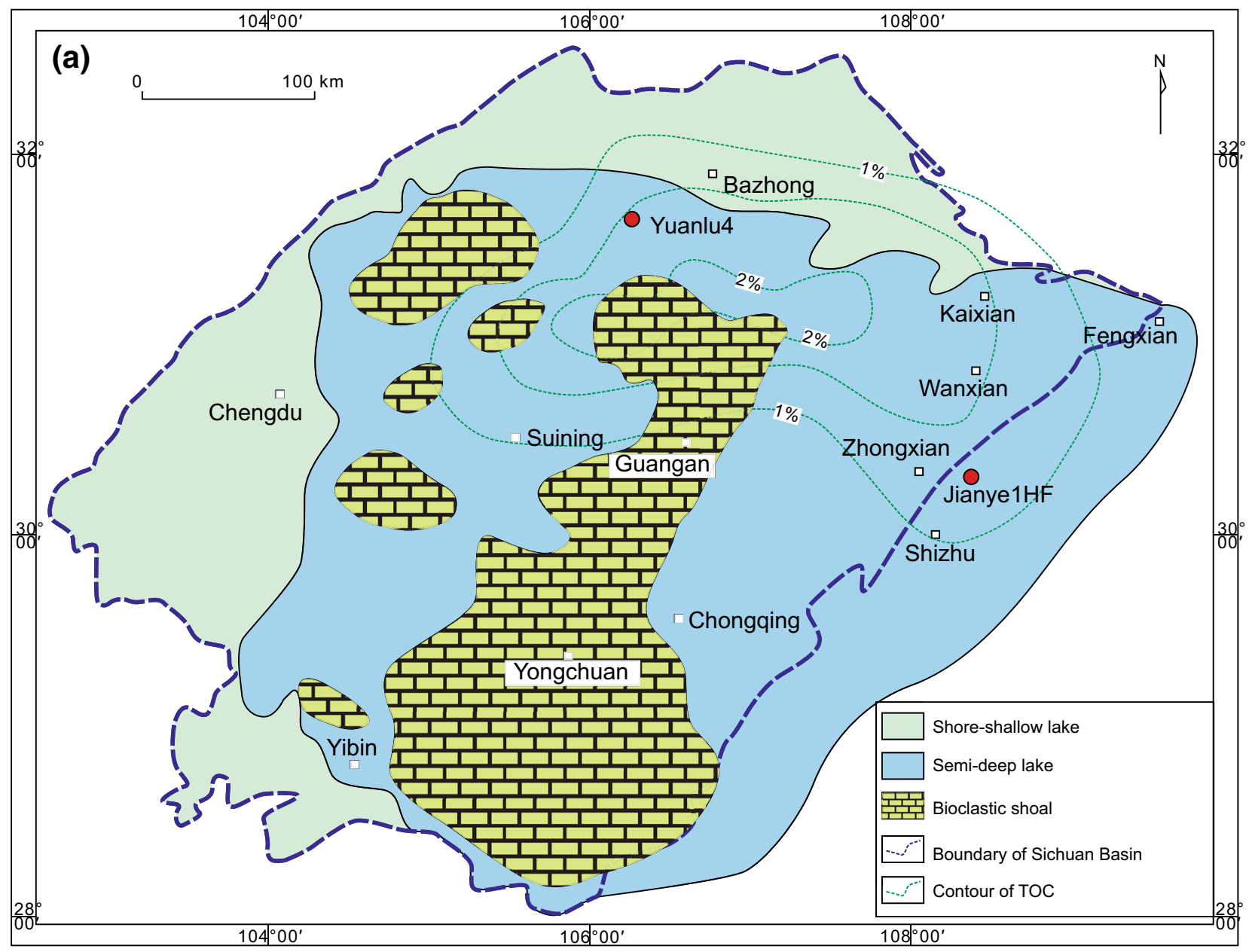

(b)

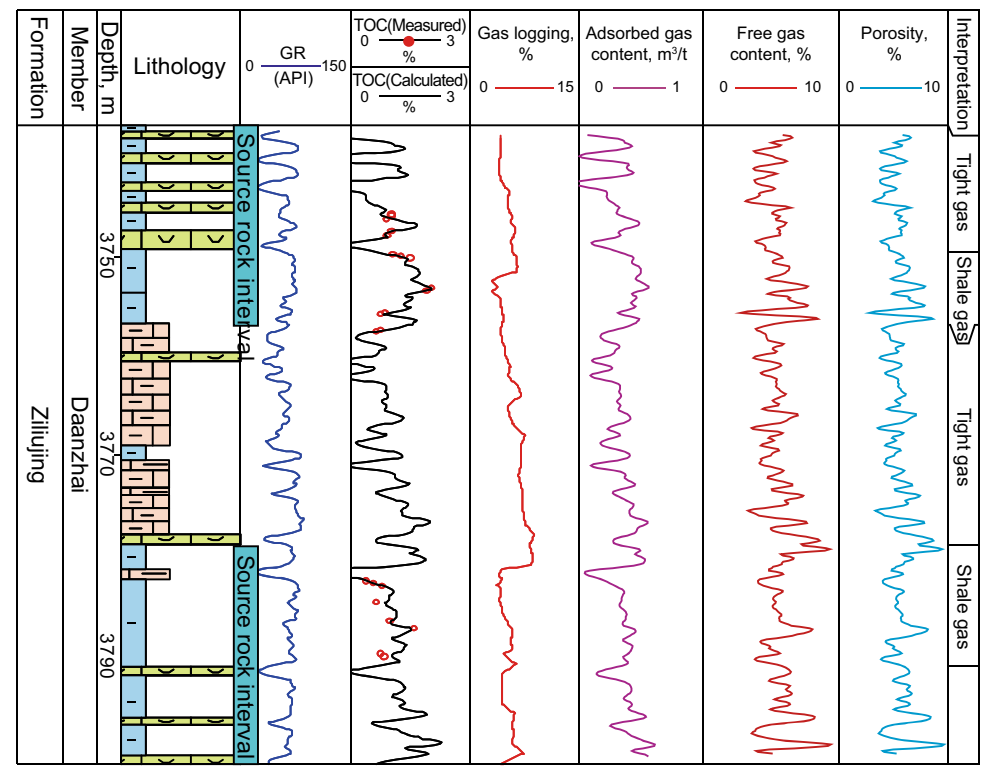

Yuanlu4

¿ Bioclastic limestone (c)

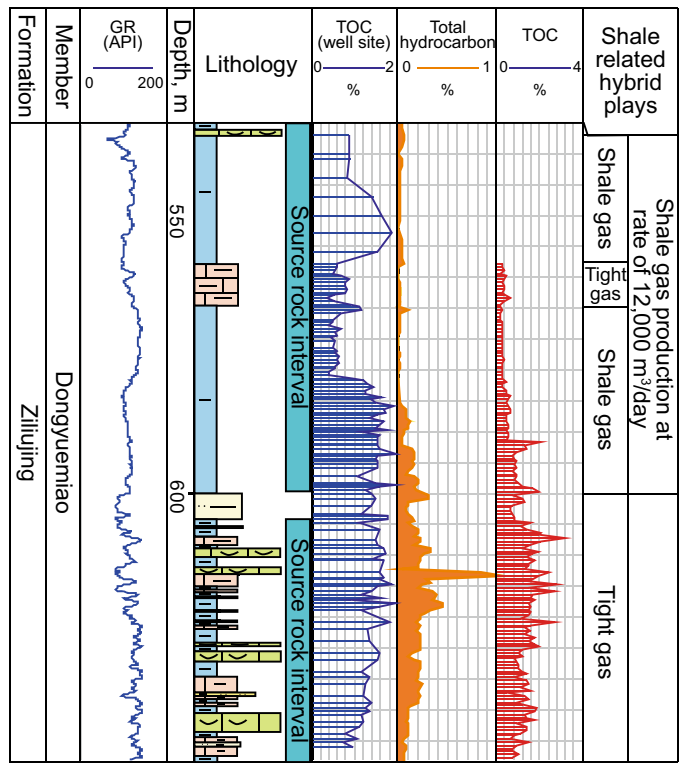

..- Silty shale $-\ldots \cdot$ Argillaceous siltstone 
4Fig. 6 a The sedimentary facies distribution and TOC contour map of the Da'anzhai Member of the Lower Jurassic Ziliujing Formation in the Sichuan Basin (After Jin et al. 2013 and Li et al. 2013b); b "Hybrid Plays" in the Lower Jurassic Ziliujing Formation in the vertical Yuanlu4 well, original data courtesy of Sinopec; c "Hybrid Plays" in the Lower Jurassic Ziliujing Formation in the horizontal Jianye1HF well (modified and interpreted from Jin et al. 2013). This is a horizontal well and the data shown in $\mathbf{c}$ are from the drilling and logging results before the well was sidetracked to a horizontal lateral. The "Hybrid Plays" were identified based on lithofacies, geochemistry, petrophysics, and production test results

of shale and tight carbonate plays in the Da' anzhai Member of the Lower Jurassic Ziliujing Formation in northeastern Sichuan Basin. The vertical XL101 well in southeastern Sichuan Basin yielded shale gas flows of $11 \times 10^{4} \mathrm{~m}^{3}$ $\left(385 \times 10^{4} \mathrm{ft}^{3}\right) /$ day from similar "Hybrid Plays." The horizontal Shiping 2-2H well in the northeastern Sichuan Basin produced condensate oil from "Hybrid Play" shales and carbonate reservoirs at rates of 33.79 tonnes (250 barrels)/day based on 24-h performance test. Many oilfields in Central North Sichuan Basin (e.g., Gongshanmiao, Shilongchang, Zhongtaishan, Guihua, etc.) share similar characteristics of regionally continuous hydrocarbon accumulations. Historically, tight oil production from the Gongshanmiao Oilfield was primarily from the targeted bioclastic limestone interbeds (porosity of $2 \%$ and permeability of $0.057 \mathrm{mD}$ ) within the organic-rich Da'anzhai shale source rock interval (Jin et al. 2014). All these analyses and production results demonstrate the similarities between the Jurassic lacustrine Ziliujing play and the Bakken or Niobrara "Hybrid Plays." In all cases, the major oil production contribution is related to tight carbonates and minor production contributions are from shale with maturity levels ranging from $0.7 \%$ to $1.1 \%$. The organicrich shale plays a significant role in gas production from this "Hybrid Play" system within source rock intervals with maturity levels of $1.1 \%-1.4 \%$.

\subsection{Hybrid Plays within Upper Cretaceous siliciclastic source rock in the Songliao Basin}

The Songliao Basin covers $260,000 \mathrm{~km}^{2}$ and is a largescale Mesozoic-Tertiary lacustrine basin in northeast China (Fig. 1). The largest oilfield-Daqing Oilfield-is located in the north-central area of this basin. The Songliao Basin originated with extensional faulting during the Triassic to the Middle Jurassic, followed by a rifting stage in the Late Jurassic. The post-rift stage with a large-scale thermal subsidence depression extended from Early to Late Cretaceous and uncomfortably overlays the syn-rift strata (Feng et al. 2010). The fault-bounded sediment fill in the syn-rift and widespread post-rift sediment fill generally thin toward the basin margins, resulting in steer's-head geometry in cross section (Feng et al. 2010). The sedimentary filling of this basin is dominated by Upper Cretaceous strata, which serve as the main petroleum source and reservoir system. The main source rock in this basin is the thick, dark, and organic-rich Upper Cretaceous Qingshankou shale deposited in an anoxic deep lake setting during a period of high-stand lake levels (Liu et al. 2014).

The Qingshankou Formation (Fm.) was deposited in a semi-deep to deep lake that occupied a large area of the Songliao Basin. The Qingshankou shale source rocks cover an area of $40,000 \mathrm{~km}^{2}$ and have TOC ranges $>2 \%$ in the basin center, $R_{\mathrm{o}}$ values of $0.7 \%-1.5 \%$ and thicknesses of 50-400 m (Feng et al. 2010; Fig. 7a). Within the Qingshankou source rock interval, the organic-rich shale in semi-deep to deep lake settings are often associated with thin siliciclastic silty shale, turbidite sandstones, siltstone, and sandy mass transport deposits (MTDs), even occasionally associated with ostracod grainstone and marls (Pan et al. 2014; Fig. 7b-d). Altogether these regionally correlated, interbedded lithologies within the Qingshankou interval form "Hybrid Plays."

Another example of a "Hybrid Play" in the northern Songliao Basin is shown in the vertical Ha14 well yielding oil at rate of 1.36 tonnes (10 barrels)/day and gas at a rate of $1253 \mathrm{~m}^{3}\left(43,855 \mathrm{ft}^{3}\right) /$ day (based on 24-h performance test from the Qingshankou source rock interval consisting of siliciclastic shale and tight siltstone interbeds (Fig. 7c). Its neighbor well Ha18 also produced oil at a rate of 10 tonnes (73 barrels)/day from a "Hybrid Play" system consisting of interbedded shale and tight siltstone. The NGN1 well in the southern Songliao Basin clearly demonstrates that the siltstone, silty shale and sandstone interbeds, and shale have significant oil content (Fig. 7b), confirming the reservoir potential of shale, tight siltstone and sandstone reservoirs in this "Hybrid Play."

\subsection{Hybrid Plays within Paleogene mixed siliciclastics and carbonate source rock in the onshore Bohai Bay Basin}

The Bohai Bay Basin located in eastern China has been producing conventional oil and gas since 1961. The major source rock intervals include the Eocene Upper 4th member of the Shahejie Fm. $\left(E_{4}\right)$ deposited in a saline lake environment and the 3rd member of the Shahejie Fm. $\left(\mathrm{Es}_{3}\right)$ deposited in a brackish to fresh lake setting (Zhu et al. 2004). The high TOC associated with gypsum and carbonate is due to the good preservation of organic matter in the stratified saline to brackish lakes, where anoxic depositional settings and low detrital dilution allow the deposition of laminated organic-rich shale. Regionally, the Es 3 shale with thicknesses up to $500 \mathrm{~m}$ and TOC up to $14 \%$ is the most significant source rock for the conventional 


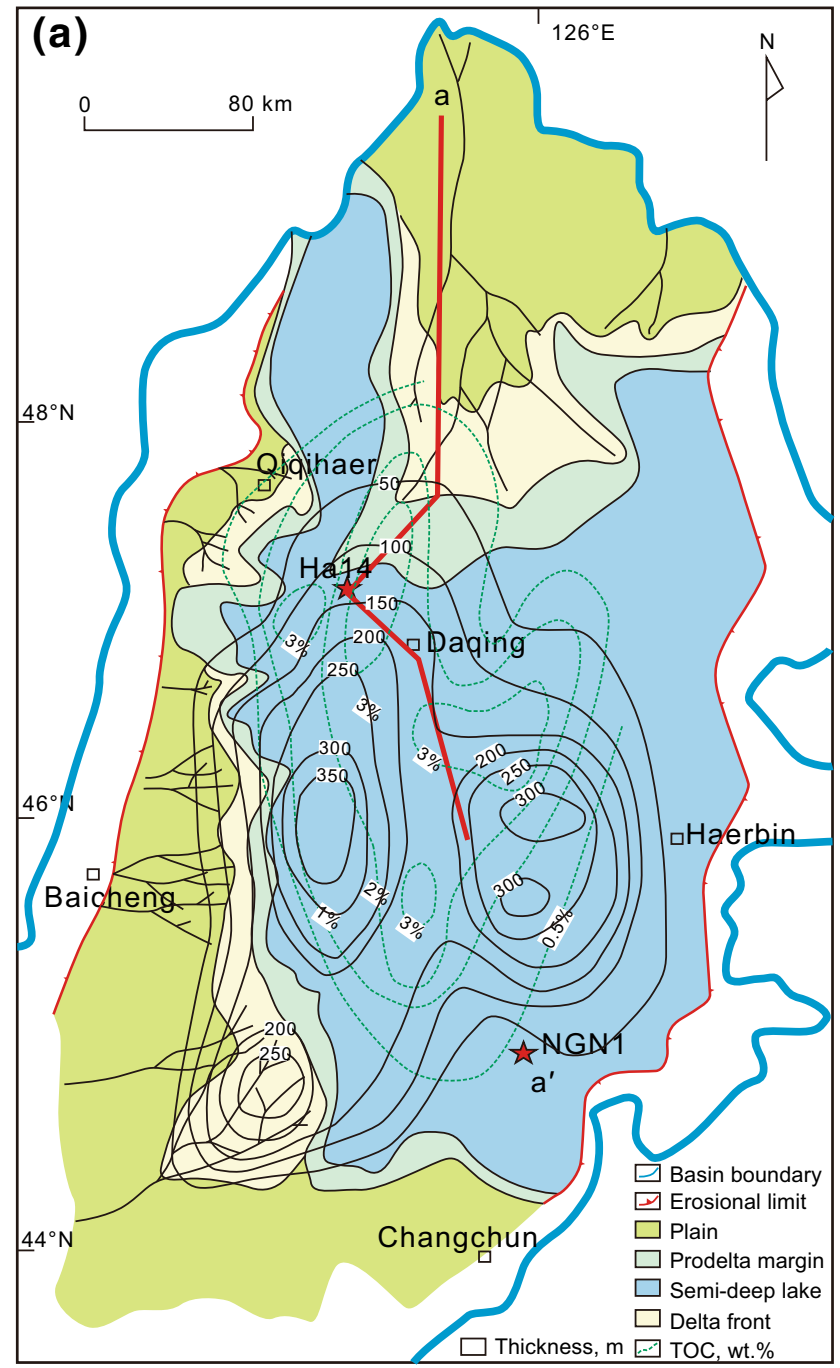

(b) NGN1 well

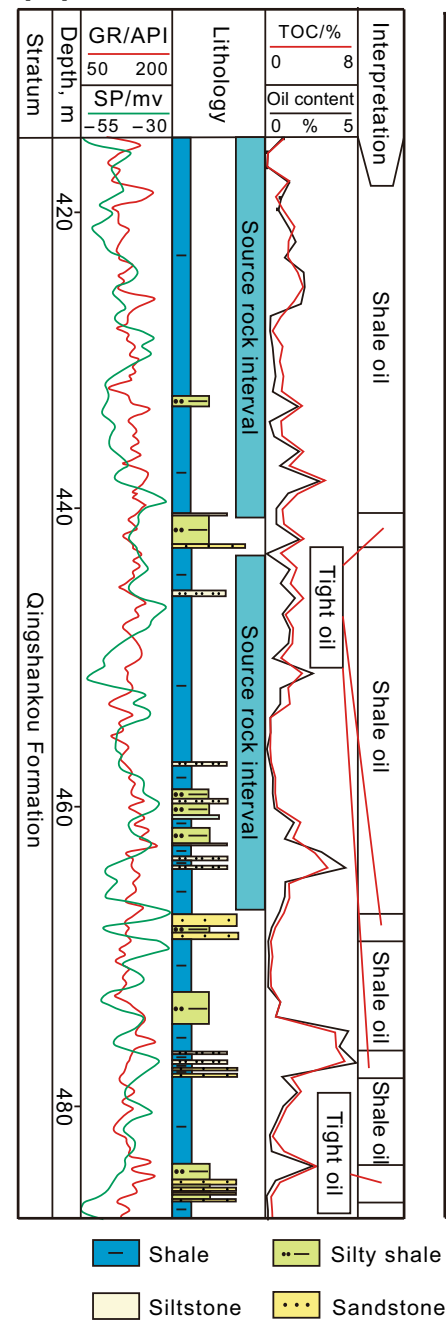

(c) Ha14 well

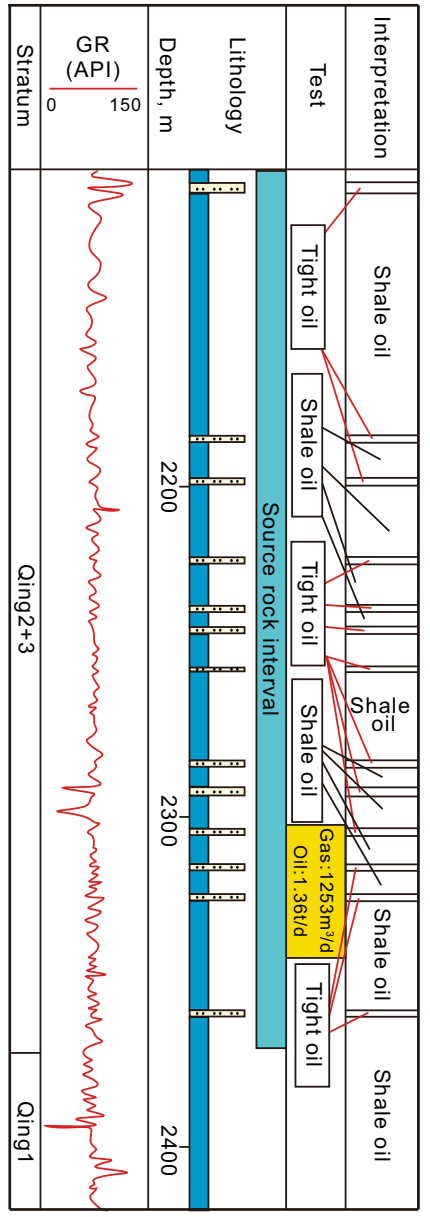

A... Argillaceous siltstone $a^{\prime}$ Ne5 Ne1 Tong1 Linshen1 Li2

(d)

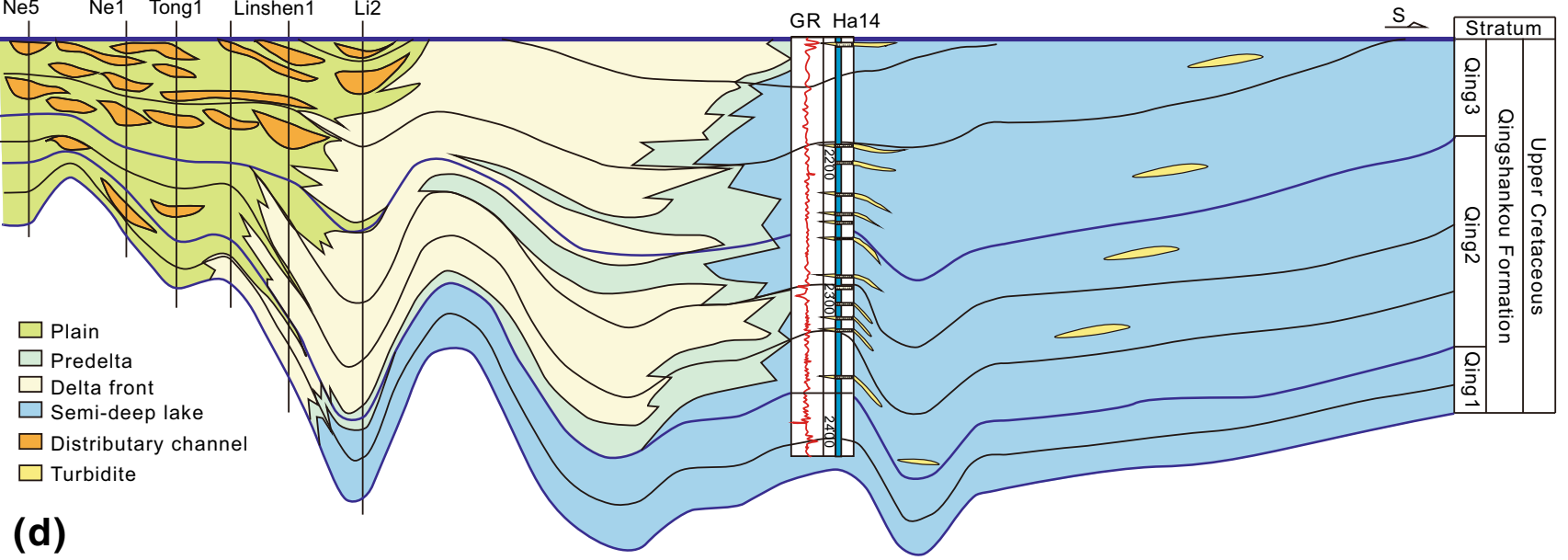


4Fig. 7 a The sedimentary facies distribution and TOC contour of the Upper Cretaceous Qingshankou Fm. in the Songliao Basin (modified from Feng et al. 2010); b "Hybrid Plays" in the Upper Cretaceous Qingshankou source rock interval in the vertical NGN1 well (reinterpreted from Liu et al. (2011) based on lithofacies characteristics and production test results). The "Hybrid Plays" were identified based on the lithofacies, geochemistry, and production test results. See a for well location; c "Hybrid Plays" in the Upper Cretaceous Qingshankou source rock interval in vertical Ha14 well (modified and reinterpreted from Li et al. 2012). See a for well location; d Northsouth cross section showing the sedimentary facies distribution of the Upper Cretaceous Qingshankou Fm. in the Songliao Basin. See a for the location of the cross section

deltaic sandstone reservoirs in Bohai Bay Basin. From an exploration and interpretation point of view, the Bohai Bay Basin is a mature basin. Exploration has focused on the lenticular turbidite sandstones, thin carbonate, tight sandstones, and shale resources in $\mathrm{Es}_{3}$ across many sub-basins that share similar depositional history in the Bohai Bay Basin (Zhang et al. 2012b; Jiu et al. 2013; Jiang et al. 2013a, b; Yang et al. 2016). For the purpose of characterizing "Hybrid Plays," the Jiyang Sub-basin is used as a representative petroleum system in the Bohai Bay Basin.

During the Paleogene Shahejie Fm. depositional period, the semi-deep to deep lake facies dominated the majority of the Jiyang Depression with deltas and alluvial fans developing near the uplifts (Fig. 8a, c). Due to turbidite deposition in semi-deep to deep lake settings (Fig. 8a, c), the source rock interval is commonly interbedded with sandstone and siltstone (Fig. 8b). From the Niu38, He160 and Yi170 wells, it was determined that the $\mathrm{Es}_{3}$ source rock interval has a TOC of $1 \%-4 \%$ throughout the stratigraphic succession of organic-rich shale interbedded with sandstone, siltstone, gypsodolomite, and dolomite. The hydrocarbons are present in the whole source rock interval based on the hydrogen index (HI) or total hydrocarbons from mud logging readings. It appears that the sandstone, siltstone, and dolomite interbeds have a higher content of hydrocarbons than the shales (Fig. 8b). Generally, the data reveal that the hydrocarbons are trapped in "Hybrid Plays" consisting of siliciclastic shale, silestone, and sandstones and carbonates throughout the $\mathrm{Es}_{3}$ source rock interval. Previous study by Pang et al. (2004) indicates approximately $40 \%$ of the generated hydrocarbons have been expelled into conventional traps, therefore as much as $60 \%$ of the generated hydrocarbons may be hosted in the "Hybrid Plays" of the $\mathrm{Es}_{3}$ source rock interval in the Jiyang Basin. Besides the hybrid unconventional tight siliciclastic and carbonate plays, conventional turbidite reservoirs may also be present in the $\mathrm{Es}_{3}$ source rock interval and form a combination of hybrid unconventional and conventional plays depending on stratigraphic levels and rock properties, e.g., the conventional turbidite reservoir from the 2930-2950 m interval in the Niu38 well in Fig. 8b. Historical production data and recent drilling have confirmed the abundance of "Hybrid Plays" in the Jiyang Sub-basin and other sub-basins of the Bohai Bay Basin. For example, the shale oil and gas production from the naturally fractured $\mathrm{Es}_{3}$ shale in the Zhanhua Depression of the Jiyang Sub-basin was first reported in the early 1960s. So far, about 130 wells have encountered shale oil and gas shows and over 30 wells have produced commercial quantities of shale oil with high production rates of $90+$ tonnes $(666+$ barrels)/day. The He54 well in the Dongying Depression in the Jiyang Sub-basin produced at a rate of 91.3 tonnes (676 barrels)/day ( $\mathrm{Li}$ et al. 2006; Jiu et al. 2013) and the Lei88 and Shugu 165 wells produced oil at rates of 47 tonnes (345 barrels)/day and 21 tonnes (154 barrels)/day, respectively, from $\mathrm{Es}_{3}$ hybrid tight carbonate and shale plays in Liaohe Sub-basin. The Pushen18-1, Wengu4 and horizontal Baimiaoping1 wells produced oil at initial rates of 420 tonnes ( 3108 barrels)/day, 120 tonnes (888 barrels)/day, and 40 tonnes (296 barrels)/day, respectively, from Hybrid Plays of tight sandstone and fractured shale in the Dongpu Sub-basin.

\section{Characteristics summary of source rock intervals and "Hybrid Plays" in China's lacustrine basins}

Based on extensive synthesis of the geology, geochemistry, mineralogy, petroleum systems, and production data for the key representative Permian to Cenozoic source rocks of lacustrine basins in China, the properties of the identified "Hybrid Plays" are summarized in Table 3. The common characteristics of these "Hybrid Plays" include:

1. They are all organic-rich (mostly $>2 \%$ ) shale related plays in the source rock interval in terms of genetic, stratigraphic and depositional association, hydrocarbon generation, and migration;

2. They have mixed plays with siliciclastic reservoirs and/or carbonates;

3. Most "Hybrid Play" reservoirs are very tight (permeability $<0.1 \mathrm{mD}$ ) with the exception of a few conventional reservoirs with high porosity and high permeability e.g., turbidite sandstone;

4. In China, most "Hybrid Plays" in lacustrine basins are overpressured with pressure coefficients of 1.2-2 except for the regionally underpressured (pressure coefficients of 0.7-0.9) Upper Triassic Hybrid Plays in the Ordos Basin (Table 3). Overpressure is a production benefit and can enhance the flow of hydrocarbons to the wellbore. 


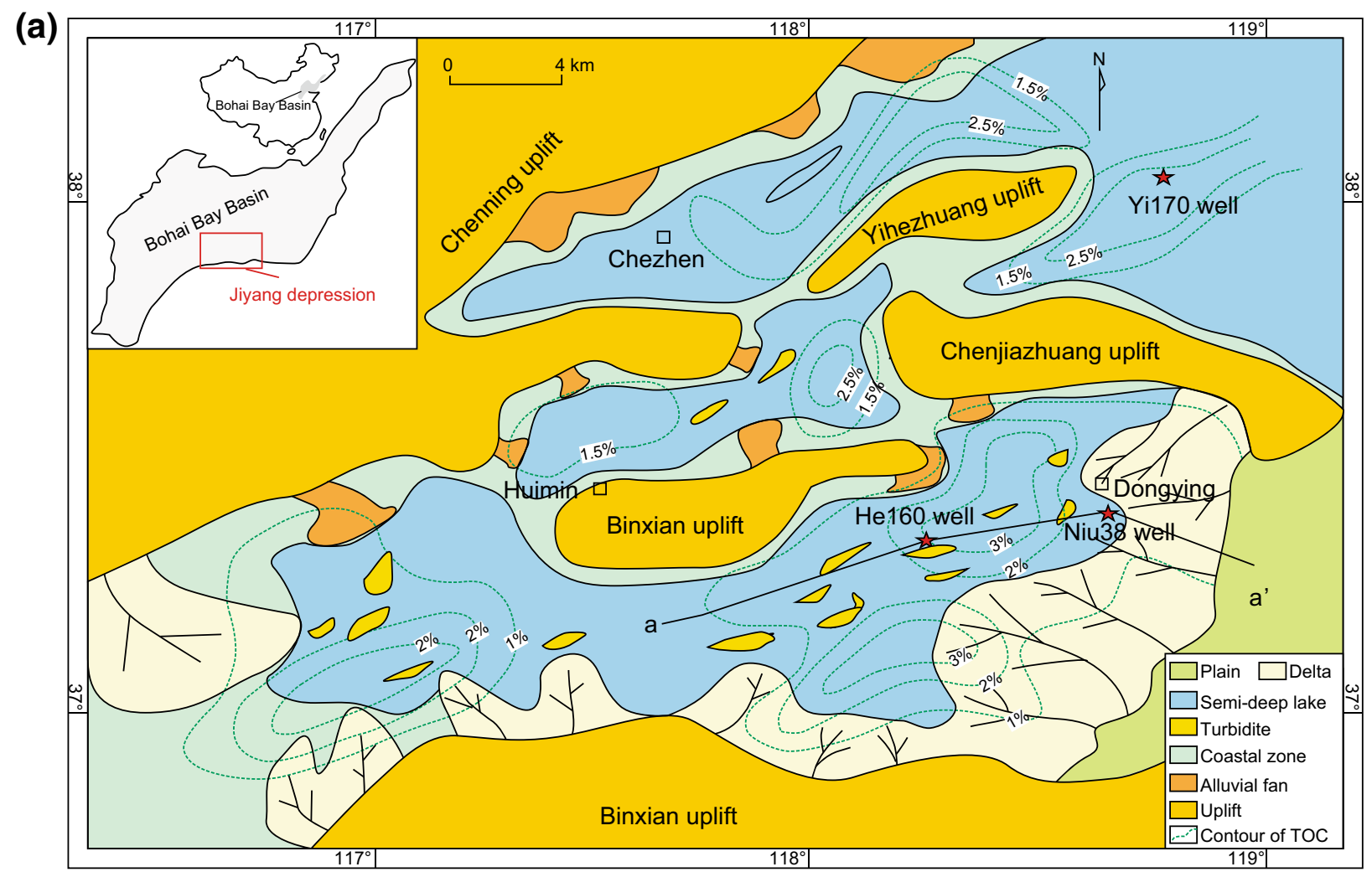

(b)

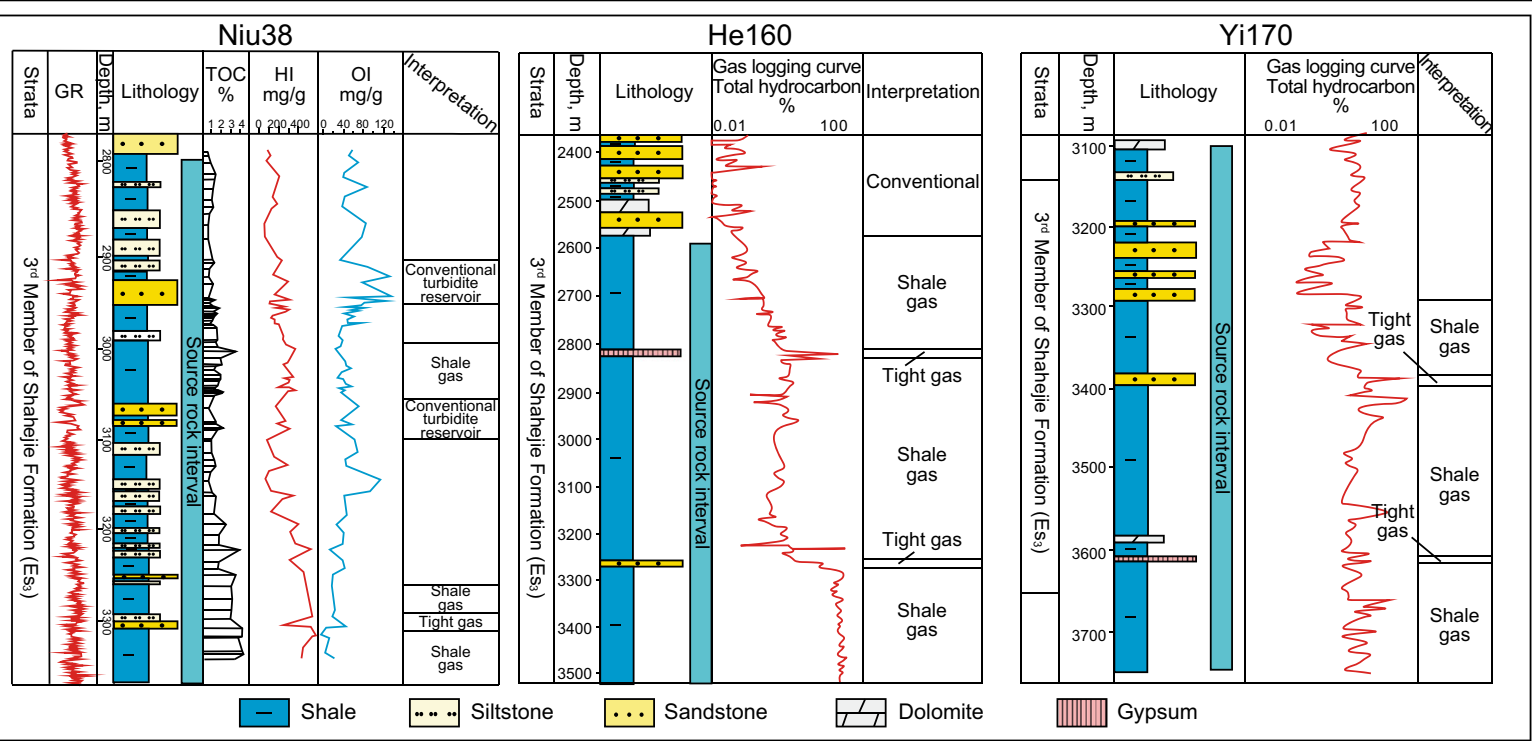

(c)

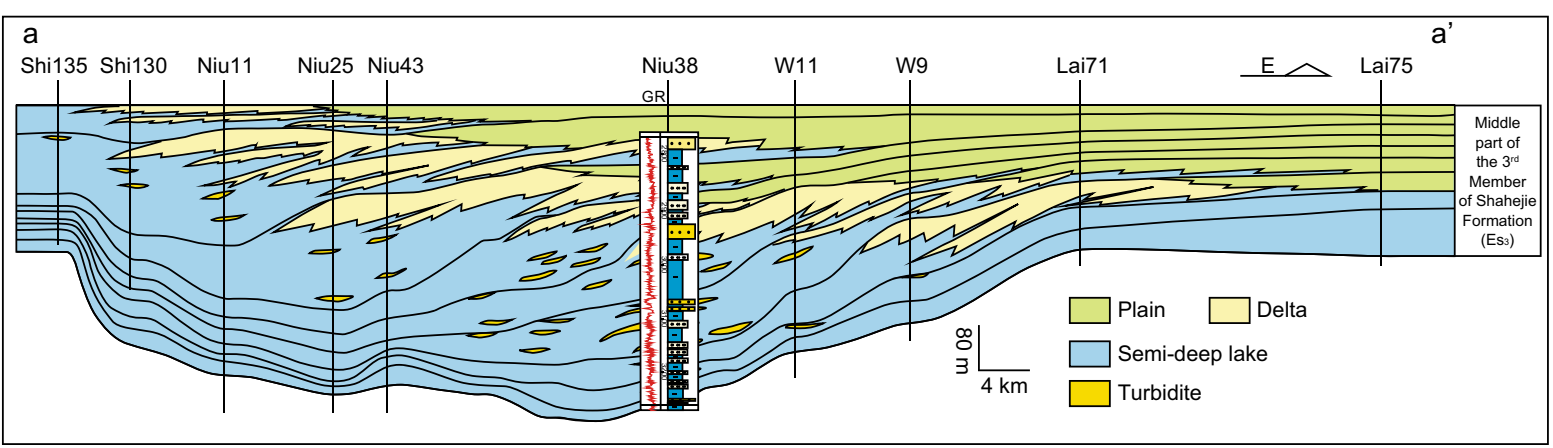


4 Fig. 8 a The sedimentary facies distribution and TOC contour map of the 3rd Member of the Shahejie Formation $\left(\mathrm{Es}_{3}\right)$ in the Jiyang Depression, Bohai Bay Basin (Modified from Jiu et al. 2013); b Hybrid Plays in the 3rd Member of Shahejie Formation $\left(\mathrm{Es}_{3}\right)$ source rock interval in vertical Niu 38, He160 and Yi170 wells (original well data from Zhang et al. (2008b), see a for well locations). The Hybrid Plays were identified based on the lithofacies, geochemistry, and production test results; c West-east cross section showing the $\mathrm{Es}_{3}$ sedimentary facies variation (Section location in a), compiled and reinterpreted from data published by Zhang et al. (2008b) and Jiu et al. (2013)

The Permian to Cenozoic lacustrine source rocks in China were deposited in shallow to deep lakes in hypersaline to fresh water, in the basin center far away from clastic dilution. The source rock intervals have unique hybrid lithofacies associations based on age, tectonics, and depositional settings and are potential reservoirs for "Hybrid Plays" include organic-rich facies and organic-lean facies exampled below:

1. Organic-rich black shales interbedded with organic,carbonate and silt rich shale (e.g., carbonate-rich shale with $\mathrm{TOC}>3 \%$ in the Middle Permian Lucaogou source rock interval in the Junggar Basin in Fig. 3b);
2. Organic-lean carbonate (e.g., marl and bioclastic limestone interbedded in Jurassic Ziliujing source rock intervals in the Sichuan Basin in Fig. 6b, c);

3. Organic-lean sandstone and siltstone (e.g., in Upper Triassic Chang7 source rock in the Ordos Basin, Upper Cretaceous Qingshankou source rock interval in the Songliao and Cenozoic $\mathrm{Es}_{3}$ source rock interval in the Bohai Bay Basin).

China has lacustrine rift, sag and foreland basins according to their tectonic settings (Fig. 9a-c), e.g., the Paleogene Bohai Bay Basin and Jianghan Basin are lacustrine rift basins, the late Cretaceous Songliao Basin is a sag basin, and the Middle Permian Santanghu Basin, late Triassic Sichuan Basin, Jurassic Junggar Basin, and Triassic Ordos Basin are lacustrine foreland basins. Taking into account the lacustrine basin forming regime, lithofacies, geochemistry, reservoir properties, and hydrocarbon generation and accumulation for the "Hybrid Plays" in the lacustrine source rock interval and conventional plays, petroleum system models have been established for China's lacustrine rift, sag and foreland basins (Fig. 9a-d), which clearly show the types of "Hybrid Plays" in the lacustrine source rock interval and their relationships with

Table 3 Properties of "Hybrid Plays" in source rock intervals of major lacustrine basins in China (most data based on $1000+$ sample tests compiled from Zou et al. (2010, 2013a, b, 2014) and Jiang et al. (2015)

\begin{tabular}{|c|c|c|c|c|c|c|c|}
\hline Basin & Age & Typical Hybrid Plays & $\begin{array}{l}\text { TOC } \\
\text { range/ } \\
\text { average } \\
(\%)\end{array}$ & $\begin{array}{l}\text { Maturity/ } \\
\text { hydrocarbon } \\
\text { type }\end{array}$ & $\begin{array}{l}\text { Tight rock porosity } \\
(\%)\end{array}$ & $\begin{array}{l}\text { Tight rock } \\
\text { permeability, } \\
\mathrm{mD}\left(10^{-3} \mu \mathrm{m}^{2}\right)\end{array}$ & $\begin{array}{l}\text { Pressure } \\
\text { coefficient }\end{array}$ \\
\hline $\begin{array}{l}\text { Bohai Bay } \\
\text { Basin }\end{array}$ & $\begin{array}{l}\text { Paleogene } \\
\text { (E) }\end{array}$ & $\begin{array}{l}\text { Shahejie shales }\left(\mathrm{Es}_{3} \text { and } \mathrm{Es}_{4}\right) \text {, } \\
\text { tight carbonate, tight } \\
\text { sandstone and siltstone }\end{array}$ & $\begin{array}{l}0.5-14 / \\
3.5\end{array}$ & $\begin{array}{l}0.5-1.7 / \text { oil } \\
\text { and gas }\end{array}$ & $\begin{array}{l}0.5-12 \text { for } \\
\text { carbonate and } \\
\text { sandstone }<6 \\
\text { for shale }\end{array}$ & $\begin{array}{l}0.001-1 \text { for } \\
\text { dolomite } \\
0.001-0.05 \text { for } \\
\text { shale }\end{array}$ & $1.3-1.9$ \\
\hline $\begin{array}{l}\text { Songliao } \\
\text { Basin }\end{array}$ & $\begin{array}{l}\text { Cretaceous } \\
(\mathrm{K})\end{array}$ & $\begin{array}{l}\text { Qingshankou shale oil, shale } \\
\text { gas, tight sandstone oil }\end{array}$ & $0.5-5 / 2.2$ & $\begin{array}{l}0.7-1.5 / \text { oil } \\
\text { and gas }\end{array}$ & $\begin{array}{l}8-12 \text { for siltstone } \\
3-6 \text { for shale }\end{array}$ & $\begin{array}{l}0.1-1 \text { for } \\
\text { siltstone } \\
<0.15 \text { for shale }\end{array}$ & $1.2-1.6$ \\
\hline Sichuan Basin & $\begin{array}{l}\text { Jurassic } \\
\text { (J) }\end{array}$ & $\begin{array}{l}\text { Ziliujing } \\
\text { tight carbonate and shale oil }\end{array}$ & $1-2.8 / 1.5$ & $\begin{array}{c}0.7-1.4 / \text { oil } \\
\text { and gas }\end{array}$ & $\begin{array}{l}2-5 \text { for shale and } \\
\text { carbonate }\end{array}$ & $\begin{array}{l}0.03-0.65 \text { for } \\
\quad \text { carbonate } \\
<0.001 \text { for shale }\end{array}$ & $1.2-1.7$ \\
\hline Sichuan Basin & $\begin{array}{l}\text { Late } \\
\text { Triassic } \\
\text { (T) }\end{array}$ & $\begin{array}{l}\text { Xujiahe } 5 \text { tight sandstone gas } \\
\text { and shale gas }\end{array}$ & $\begin{array}{c}0.4-16 / \\
2.35\end{array}$ & $1.1-1.7 / \mathrm{gas}$ & $\begin{array}{l}3-10 \text { for sandstone } \\
<5 \text { for shale }\end{array}$ & $\begin{array}{l}<0.1 \text { for } \\
\text { sandstone } \\
<0.001 \text { for shale }\end{array}$ & $1.3-2$ \\
\hline Ordos & $\begin{array}{l}\text { Late } \\
\text { Triassic } \\
\text { (T) }\end{array}$ & $\begin{array}{l}\text { Yanchang7 (Chang7) } \\
\text { shale gas, tight sandstone oil, } \\
\text { shale oil }\end{array}$ & $\begin{array}{c}0.3-36 / \\
8.3\end{array}$ & $\begin{array}{l}0.5-1.2 / \\
\text { Mainly oil } \\
\text { and some } \\
\text { gas }\end{array}$ & $\begin{array}{l}\text { Tight sand: } 7-10 \\
\text { Shale: } 2-5\end{array}$ & $\begin{array}{l}0.01-0.1 \text { for } \\
\text { sandstone } \\
<0.01 \text { for shale }\end{array}$ & $0.7-0.9$ \\
\hline $\begin{array}{l}\text { Junggar, } \\
\text { Santanghu, } \\
\text { Turpan- } \\
\text { Hami }\end{array}$ & $\begin{array}{l}\text { Late } \\
\text { Permian } \\
\text { (P) }\end{array}$ & $\begin{array}{l}\text { Lucaogou } \\
\text { tight dolomite oil, shale oil }\end{array}$ & $0.7-21 / 3$ & $\begin{array}{l}0.5-1.2 / \\
\text { Mainly oil } \\
\text { and some } \\
\text { gas }\end{array}$ & $\begin{array}{l}2-9 \text { for dolomite } \\
<5 \text { for shale }\end{array}$ & $\begin{array}{l}0.01-0.1 \text { for } \\
\text { dolomite } \\
<0.01 \text { for shale }\end{array}$ & $1-1.2$ \\
\hline
\end{tabular}

The porosity and permeability data for Ordos and Bohai Bay basins are based on 56 samples that were measured by Schlumberger-TerraTek in Salt Lake City 
conventional plays. Even though the rift, sag and foreland lacustrine basins vary in basin configuration, sediments filling sequence, lithofacies, evolution of environment, structure, traps, and play types (Fig. 9a-c), these basins share the similar features of "Hybrid Plays" including the stratigraphically associated shale gas, turbidite conventional gas, shale oil, tight oil and turbidite conventional oil in the source rock interval (Fig. 9d). The shale source rocks in these three types of basins have high organic matter content and may contain Type I to Type III kerogen depending on the depositional environment and degree of terrestrial influence (Fig. 9). The type I and type II kerogen are usually present during the early rift stage and the type II and type III are present in the late rift stage with influence of terrestrial plants. The majority of generated hydrocarbons are still trapped in organic-rich shale forming selfsourced shale plays. A portion of the expelled hydrocarbons migrated to adjacent, coarser (compared to shale) siliciclastic and carbonate interbeds that are in direct contact with shale source rocks. These coarser interbeds form tight or conventional plays depending on reservoir porosity, permeability and hydrocarbon mobility. The juxtaposed tight/conventional carbonate and sandstone and shale oil accumulations occur where source intervals are in the oil-generating window in the shallow parts of the basins, whereas the juxtaposed tight/conventional and shale gas accumulations are usually located within the gas-generating window in deeper parts of the basins. These multiple-stacked siliciclastic and carbonate plays are associated with the organic-rich shale from which the oil and gas have been generated, expelled, and capped. The classic conventional hydrocarbons (except for turbidite conventional traps in source rock intervals) generally accumulate in conventional structural and stratigraphic traps above, below or around the source rock pod (Fig. 9ad). Usually, the "Hybrid Play" systems in the source rock intervals are closed petroleum systems that are self-sourced or adjacently sourced. The reservoirs of the "Hybrid Plays" range from extremely tight shale to tight siltstone, sandstone, carbonate, and to conventional reservoirs. These hybrid plays with mixed siliciclastics and/or carbonate reservoirs are multiple-stacked in the source rock interval (Fig. 9a-d). The oil and gas accumulation in these "Hybrid Plays" is continuous.

\section{Discussion and conclusions}

Similar to the families of lacustrine basins in Southeast Asia, Rocky Mountains in Western US, Atlantic Margins, etc., China has a series of Mesozoic to Cenozoic hydrocarbon-producing lacustrine basins. Widespread and worldclass source rock intervals in these lacustrine basins commonly consist of very thick and regionally distributed organic-rich shale source rocks (TOC abundance up to $36 \%$ ) and thin, organic-lean siltstone, sandstone, and/or carbonate interbeds within it, making the organic-rich shale interval juxtaposed with organic-lean facies. The organicrich shale is formed in anoxic semi-deep to deep lake settings. The siltstone and sandstone are usually turbidite or mass transport deposits (MTDs). The carbonate is generally formed in saline evaporite settings when the water level is low and less clastics are input into the calm lake. For China's various lacustrine basins with different tectonic and depositional settings, the source rock intervals are both laterally and vertically heterogeneous in terms of lithofacies. The Middle Permian lacustrine mixed siliciclastic siltstone and carbonates (mainly dolomitic rock) associated with shale source rocks are present in the Junggar and Santanghu foreland basins in NW China. The siliciclastic sandstone and siltstone in association with shale source rock deposits are typically present in Upper Triassic Chang7 source rocks in the Ordos foreland basin in northern China. The Jurassic carbonates (bioclastic limestone) are predominantly found in lacustrine source rocks in the Jurassic rift stage of the Sichuan Basin. The siliciclastic thick organic-rich shale and thin sandstone and siltstone are dominant in Upper Cretaceous Qingshankou source rock in the Songliao sag Basin. Paleogene $\mathrm{Es}_{3}$ age equivalent source rocks consisting of mixed siliciclastic organic-rich shale, sandstone, siltstone and carbonate are pervasive in lacustrine rift basins in East China. The integrated evaluation of geology, geochemistry, mineralogy, petrophysics, and synthesis of scattered production tests indicate that thick organic-rich black shales serve as both source rock and reservoir and can be potential shale gas and shale oil plays depending on the maturity level of source rocks. The lenticular and blanket sandstone, carbonate and siltstone interbeds are directly in contact with shale source rocks creating an efficient charging system and are sometimes comparable to unconventional type plays that are mostly tight oil and gas plays similar to the Bakken dolomite and Niobrara chalk tight oil reservoirs. Even though the lacustrine interbeds with limited lateral extent are thinner than typical marine deposits, they could host significant amounts of hydrocarbons and be primary reservoirs since they are more porous and permeable than the adjacent shales. Industry data confirms that in some instances gas or oil was produced through more permeable and brittle sand or silt layers interbedded within the shale (Jarvie 2014). In the past, they were overlooked or ignored to some extent because the focus was directed toward unconventional exploration of regionally continuous shale and massive tight sand plays. We conclude both shale and related interbeds should be treated together as "Hybrid Plays" and expect they can host enormous continuous oil 
$R_{0} \%$

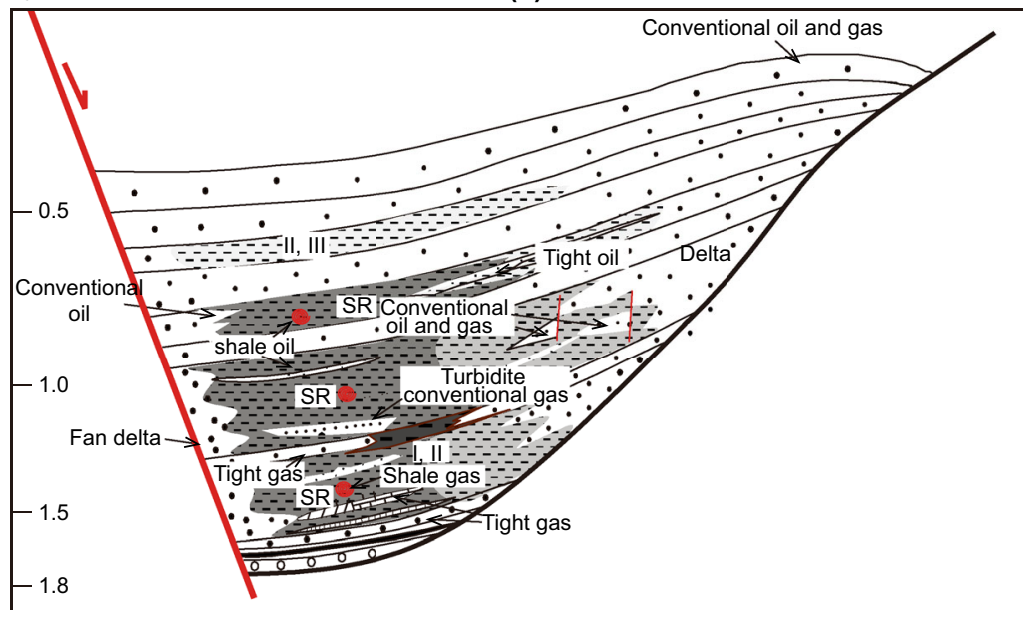

$R_{\mathrm{o}} \%$

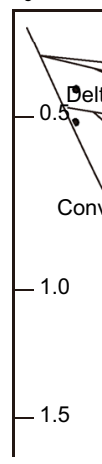

(b)

$R_{\circ} \%$

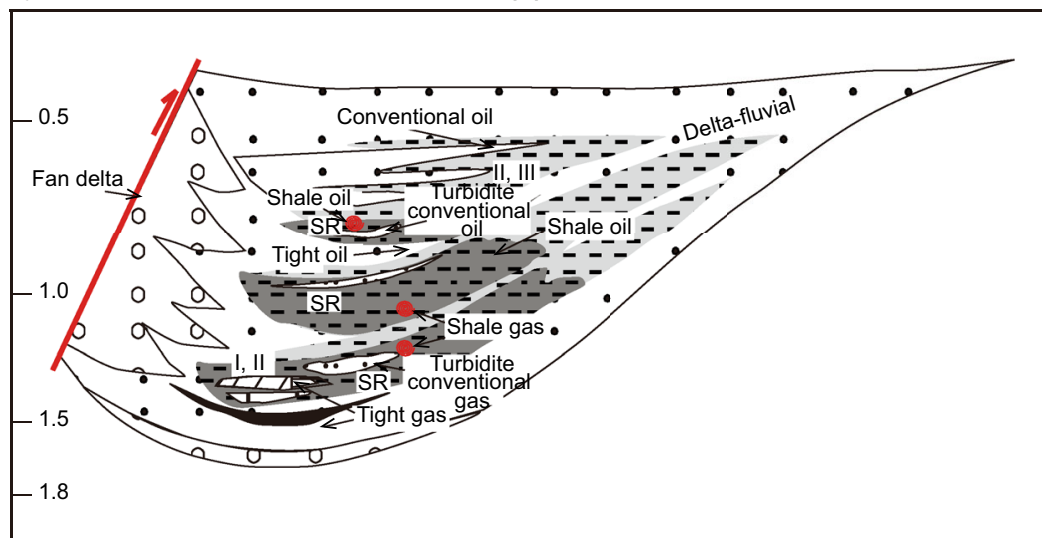

(d)

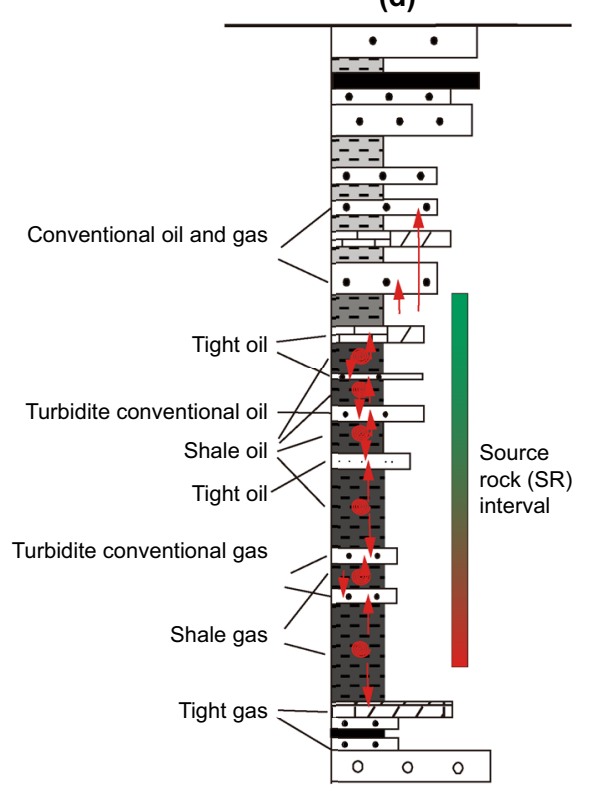

\section{Legend}

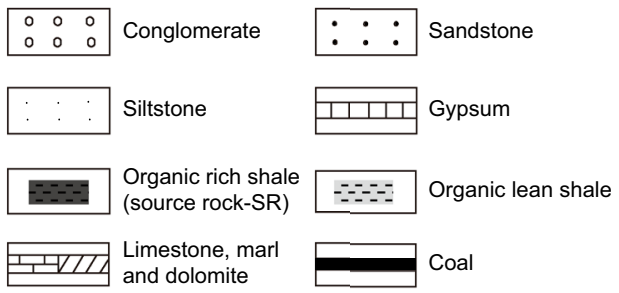

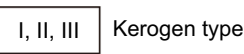

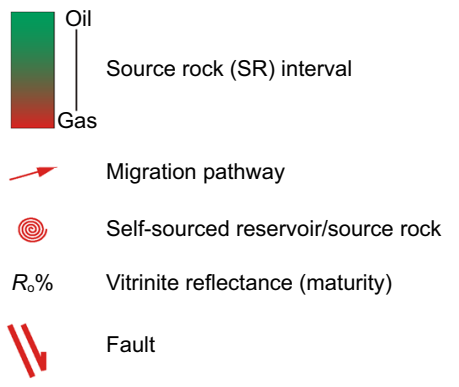

Fig. 9 Schematic diagrams showing the distribution of "Hybrid Plays" in the source rock intervals and conventional plays in the lacustrine rift basin (a), lacustrine sag basin (b), and lacustrine foreland basin (c). d shows the vertical association of various stacked "Hybrid Plays" including shale gas, turbidite conventional gas, shale

and gas accumulations in all the producing lacustrine basins in China. The "Hybrid Plays" concept revamps our understanding of lacustrine source rock reservoirs and genetically synthesizes the source to accumulation of unconventional to conventional systems in the source rock interval. "Hybrid Plays" present unique petroleum systems oil, tight siliciclastic and carbonate oil, and turbidite conventional oil in the lacustrine source rock interval

hosting continuous hydrocarbons stored in thick, selfsourcing shale reservoirs and adjacent thin coarse-grained siliciclastic and carbonate interbeds, which form hybrid siliciclastic and carbonate unconventional plays/reservoirs in addition to conventional plays/reservoirs throughout the whole source rock interval. In undrilled areas and untested 
intervals of proven source rock, the potential plays can be identified based on regional geological and geophysical interpretation, geochemical, petrophysical, mineralogical analysis, log characteristics, and oil and gas shows in mud logs, etc. These "Hybrid Plays" represent a new exploration target in the multiple-stacked lithologies of organiclean rocks juxtaposed against organic-rich shale. The potential for "Hybrid Plays" in source rocks will continue to open more prospects in previously uneconomic areas and what were considered to be uneconomic stratigraphic intervals.

The source rock interval has a much lower matrix permeability and much smaller pore throats than conventional reservoir intervals and unconventional tight siliciclastic and carbonate intervals outside the source rock. The remaining unexpelled and short distance migration hydrocarbons are available to be produced when sufficient fracture conductivity is induced by hydraulic fracturing. Many historical production cases and recent tight and shale play exploration endeavors proved the producibility of gas from both relatively coarse-grained interbedded intervals with lean organic matter and naturally fractured very finegrained tight shale with rich organic matter. The natural fractures contribute both hydrocarbon storage and production. In essence, most "Hybrid Plays" in lacustrine basins in China are multiple-stacked unconventional and conventional prospects and the resources can be produced by placing horizontal wells in the brittle sandstone or carbonate interbeds and employing multistage hydraulic fracturing techniques targeting the mixed "Hybrid Plays" to ensure the fractures are extended from the sandstone or carbonate intervals into the adjacent organic-rich shale intervals. These clay-poor and organic-lean interbeds with coarser brittle minerals usually have better reservoir quality with higher porosity and permeability and are more conductive than shale allowing oil and gas to travel to the wellbore (Chalmers et al. 2012). Since the lacustrine rocks are very heterogeneous and shale deposited in lake settings is usually clay-rich, understanding the reservoir property distribution, and the regime of waxy crude oil flow in shale along with new hydraulic fracturing technology to unlock the hydrocarbons from the shale and interbeds together require a multidisciplinary approach involving teams of geologists, engineers and other industry professionals. With the advancement of hydraulic fracturing technology for clay-rich shale, the pervasive oil accumulation in the shale interval could become far more economic viable.

We assert "Hybrid Plays" in the heterogeneous lacustrine source rock provide the most realistic exploration and production model for multiple, horizontally, and/or vertically stacked mixed conventional and unconventional siliciclastic and/or carbonate plays in order to avoid relying solely on clay-rich shale targets. The "Hybrid Plays" model has been proven and works for a wide variety of lacustrine rift, sag, and foreland basins in China. As they are exploited as future E\&P targets, "Hybrid Plays" are expected to decrease production costs by increasing the use of multiple laterals from one pad/platform and multistage hydraulic fracturing to stimulate the "Hybrid Plays" together at one time.

Acknowledgements Authors want to acknowledge National Natural Science Foundation of China (Grant Numbers 40872077 and 41272122), China National Key Technology Research and Development Program (Grant Number 2001BA605A09-1), Open fund from Sinopec's Petroleum Exploration and Production Research Institute (Grant No. G5800-15-ZS-WX038), and EGI's China Shale Gas and Shale Oil Plays Consortia (100980) sponsored by 20 multi-national oil companies. Appreciation is expressed to PetroChina and Sinopec for the privilege of working on the industry data and many other Chinese institutes for collaborating. We are also grateful for Weatherford and Schlumberger-TerraTek for their sample testing. Ms. Shuang Chen is thanked for her drafting of revised figures.

Open Access This article is distributed under the terms of the Creative Commons Attribution 4.0 International License (http://crea tivecommons.org/licenses/by/4.0/), which permits unrestricted use, distribution, and reproduction in any medium, provided you give appropriate credit to the original author(s) and the source, provide a link to the Creative Commons license, and indicate if changes were made.

\section{References}

Bohacs KM, Carroll AR, Neal JE, et al. Lake-basin type, source potential, and hydrocarbon character: an integrated sequencestratigraphic-geochemical framework. Lake basins through space and time. AAPG Stud Geol. 2000;46:3-4. doi:10.1306/ St46706C1.

Bustin MR. Geology report: where are the high-potential regions expected to be in Canada and the US? Capturing opportunities in Canadian shale gas. In: The Canadian Institute's 2nd Annual Shale Gas Conference, January 31-February 1, Calgary; 2006.

Cao J, Zhang Y, Hu W, et al. The Permian hybrid petroleum system in the northwest margin of the Junggar Basin, northwest China. Mar Pet Geol. 2005;22(3):331-49. doi:10.1016/j.marpetgeo. 2005.01.005.

Carroll AR. Upper Permian lacustrine organic facies evolution, southern Junggar Basin, NW China. Org Geochem. 1998;28(11):649-67.

Carroll AR, Bohacs KM. Stratigraphic classification of ancient lakes: balancing tectonic and climatic controls. Geology. 1999;27(2):99-102. doi:10.1130/0091-7613.

Chalmers GRL, Bustin RM, Bustin AAM. Geological controls on matrix permeability of the Doig-Montney hybrid shale-gastight-gas reservoir, northeastern British Columbia (NTS 093P); in Geoscience BC Summary of Activities 2011, Geoscience BC, Report 2012-1; 2012. p. 87-96.

Chen Q, Li W, Gao Y, et al. The deep-lake deposit in the Upper Triassic Yanchang Formation in Ordos Basin, China and its significance for oil-gas accumulation. Sci China Ser D Earth Sci. 2007;50(2):47-58. doi:10.1007/s11430-007-6029-7.

Clarkson CR, Pedersen PK. Production analysis of Western Canadian unconventional light oil plays. In: Canadian Unconventional Resources Conference 2011 Jan 1. Society of Petroleum Engineers. Calgary, 15-17 November, Alberta, Canada. 
Cohen AS. Paleolimnology: the history and evolution of lake systems. Oxford: Oxford University Press; 2003. p. 350.

Curtis JB. Fractured shale-gas systems. AAPG Bull. 2002;86(11):1921-38. doi:10.1306/61EEDDBE-173E-11D78645000102C1865D.

Doust H, Sumner HS. Petroleum systems in rift basins-a collective approach in Southeast Asian basins. Pet Geosci. 2007;13(2):127-44. doi:10.1144/1354-079307-746.

Du J, Liu H, Ma D, et al. Discussion on effective development techniques for continental tight oil in China. Pet Explor Dev. 2014;41(2):217-24. doi:10.1016/S1876-3804(14)60025-2.

EIA. EIA/ARI World Shale Gas and Shale Oil Resource Assessment Technically Recoverable Shale Gas and Shale Oil Resources: An Assessment of 137 Shale Formations in 41 Countries outside the United States. US Energy Information Administration. 2013. www.adv-res.com.

Feng ZQ, Jia CZ, Xie XN, et al. Tectonostratigraphic units and stratigraphic sequences of the nonmarine Songliao basin, northeast China. Basin Res. 2010;22(1):79-95. doi:10.1111/j.13652117.2009.00445.x.

Gierlowski-Kordesch EH. Lacustrine carbonates. Developments in sedimentology, vol. 61. Amsterdam: Elsevier; 2010. pp. 1-101.

Graham SA, Brassell S, Carroll AR, et al. Characteristics of selected petroleum source rocks, Xianjiang Uygur Autonomous Region, Northwest China. AAPG Bull. 1990;74(4):493-512.

Hao F, Zhang Z, Zou H, et al. Origin and mechanism of the formation of the low-oil-saturation Moxizhuang field, Junggar Basin, China: implication for petroleum exploration in basins having complex histories. AAPG Bull. 2011;95(6):983-1008. doi:10. 1306/11191010114.

Hanson AD, Ritts BD, Moldowan JM. Organic Geochemistry of oil and source rock strata of the Ordos Basin, north-central China. AAPG Bull. 2007;91(9):1273-93. doi:10.1306/05040704131.

He ZX. Tectonic evolution and petroleum in the ordos basin. Beijing: Petroleum Industry Press; 2002. p. 390 (in Chinese).

$\mathrm{Hu}$ C. Source bed controls hydrocarbon habitat in continental basins, East China. Acta Pet Sin. 1982;2(2):9-13.

$\mathrm{Hu} \mathrm{T}$, Pang X, Yu S, et al. Hydrocarbon generation and expulsion characteristics of Lower Permian P1f source rocks in the Fengcheng area, northwest margin, Junggar Basin, NW China: implications for tight oil accumulation potential assessment. Geol J. 2015;51:880-900. doi:10.1002/gj.2705.

Huang C, Zhang J, Wang H, et al. Lacustrine shale deposition and variable tectonic accommodation in the Rift Basins of the Bohai Bay Basin in Eastern China. J Earth Sci. 2015;26(5):700-11. doi:10.1007/s12583-015-0602-3.

Jarvie DM. Shale resource systems for oil and gas: part 1-shale-gas resource systems. In: Breyer JA, editor. Shale reservoirs-Giant resources for the 21st century, vol. 97. Tulsa: AAPG Memoir; 2012a. p. 69-87. doi:10.1306/13321446M973489.

Jarvie DM. Shale resource systems for oil and gas: Part 2-shale-oil resource systems. In: Breyer JA, editor. Shale reservoirs-Giant resources for the 21st century, vol. 97. Tulsa: AAPG Memoir; 2012b. p. 89-119. doi:10.1306/13321447M973489.

Jarvie DM. Components and processes affecting producibility and commerciality of shale resource systems. Geol Acta. 2014;12(4):307-25. doi:10.1344/GeologicaActa2014.12.4.3.

Jia CZ, Chi YL. Resource potential and exploration techniques of stratigraphic and subtle reservoirs in China. Pet Sci. 2004;1(2):1-2.

Jiang S, Henriksen S, Wang $\mathrm{H}$, et al. Sequence-stratigraphic architectures and sand-body distribution in Cenozoic rifted lacustrine basins, east China. AAPG Bull. 2013a;97(9):1447-75. doi:10.1306/030413I2026.

Jiang S, Dahdah N, Pahnke P, Zhang J. Comparison between marine shales and lacustrine shales in China, search and discovery article \#30316. In: AAPG Annual Convention and Exhibition, May 19-22, Pittsburgh, Pennsylvania; 2013b.

Jiang S. Prospects for shale gas development in China. Issues Environ Sci Technol. 2014;39:181-97. doi:10.1039/9781782620556.

Jiang S, Zhang J, Jiang Z, et al. Geology, resource potentials, and properties of emerging and potential China shale gas and shale oil plays. Interpretation. 2015;3(2):SJ1-3. doi:10.1190/INT2014-0142.1.

Jiang S, Xu Z, Feng Y, et al. Geologic characteristics of hydrocarbonbearing marine, transitional and lacustrine shales in China. J Asian Earth Sci. 2016;115:404-18. doi:10.1016/j.jseaes.2015. 10.016.

Jin $\mathrm{Z}$, Bo G, Wu X. Characteristics and resource potential of lacustrine shale oil and gas in China, AAPG Search and Discovery Article \#80359. In: AAPG ACE, May 19-22, Pittsburgh; 2013.

Jin T, Chen L, Guo X, et al. Geological investigation for the Da' anzhai tight oil in Gongshanmiao oilfield in Sichuan Basin. Nat Gas Explor Dev. 2014;37(3):19-23 (in Chinese).

Jin J, Xiang B, Yang Z, et al. Application of experimental analysis technology to research of tight reservoir in Jimsar Sag. Lithol Reserv. 2015;27(3):18-25. doi:10.3969/j.issn.1673-8926.2015. 03.003 (in Chinese).

Jiu K, Ding W, Huang W, et al. Fractures of lacustrine shale reservoirs, the Zhanhua Depression in the Bohai Bay Basin, eastern China. Mar Pet Geol. 2013;48:113-23. doi:10.1016/j. marpetgeo.2013.08.009.

Katz BJ. Controls on distribution of lacustrine source rocks through time and space: Chapter 4. In: Katz BJ, editor. Lacustrine basin exploration-case studies and modern analogs, vol. 50. Tulsa: American Association of Petroleum Geologists Memoir; 1990. p. $61-76$.

Katz B, Lin F. Lacustrine basin unconventional resource plays: key differences. Mar Pet Geol. 2014;56:255-65. doi:10.1016/j. marpetgeo.2014.02.013.

Kelts K. Environments of deposition of lacustrine petroleum source rocks: an introduction. Geol Soc Lond Spec Publ. 1988;40(1):3-26. doi:10.1144/GSL.SP.1988.040.01.02.

Kuang L, Tang Y, Lei D, et al. Formation conditions and exploration potential of tight oil in the Permian saline lacustrine dolomitic rock, Junggar Basin, NW China. Pet Explor Dev. 2012;39(6):700-11. doi:10.1016/S1876-3804(12)60095-0.

Kuang LC, Gao G, Xiang BL, et al. Lowest limit of organic carbon content in effective source rocks from Lucaogou Formation in Jimsar Sag. Pet Geol Exp. 2014;36(02):224-9. doi:10.11781/ sysydz201402224 (in Chinese).

Lambiase JJ. A model for tectonic control of lacustrine stratigraphic sequences in continental Rift Basins: Chapter 16. In: Katz BJ, editor. Lacustrine exploration: case studies and modern analogues, vol. 50. Tulsa: AAPG Memoir; 1990. p. 265-76.

LeFever JA. History of oil production from the Bakken Formation, North Dakota. In: Hanson WB, editor. Guidebook to geology and horizontal drilling of the Bakken Formation. Billings: Montana Geological Society; 1991. p. 3-17.

Li Y, Zhong JH, Wen ZF, et al. Oil-gas accumulation types and distribution of mudstone rocks in the Jiyang Depression. Chin J Geol. 2006;41:586-600. doi:10.1111/1755-6724.12742 (in Chinese).

Li D, Li J, Wang S, et al. Tight oil reservoir characterization of Upper Cretaceous in Songliao Basin. In: International Symposium on Shale Oil Technologies, April 16-17, 2012, Wuxi, China; 2012.

Li M, Li Z, Jiang Q, et al. Reservoir Quality, Hydrocarbon Mobility and Implications for Lacustrine Shale Oil Productivity in the Paleogene Sequence, Bohai Bay Basin. In: Adapted from oral presentation presented at AAPG annual convention and exhibition, May 19-22; 2013a. Pittsburgh, Pennsylvania. 
Li Y, Feng Y, Liu H, et al. Geological characteristics and resource potential of lacustrine shale gas in the Sichuan Basin, SW China. Pet Explor Dev. 2013b;40(4):454-60. doi:10.1016/S18763804(13)60057-9.

Liang $\mathrm{H}, \mathrm{Li} \mathrm{X}, \mathrm{Ma} \mathrm{Q}$, et al. Geological features and exploration potential of Permian Tiaohu Formation tight oil, Santanghu Basin, NW China. Pet Explor Dev. 2014;41(5):616-27. doi:10. 1016/S1876-3804(14)60073-2.

Lin L, Zhang J, Li Y, et al. The potential of China's lacustrine shale gas resources. Energy Explor Exploit. 2013;31(2):317-35. doi:10.1260/0144-5987.31.2.317.

Liu Z, Sun P, Jia J, et al. Distinguishing features and their genetic interpretation of stratigraphic sequences in continental deep water setting: a case from Qingshankou Formation in Songliao Basin. Earth Sci Front. 2011;18(4):171-80 (in Chinese).

Liu B, Lü Y, Ran Q, et al. Geological conditions and exploration potential of shale oil in Qingshankou Formation, Northern Songliao Basin. Oil Gas Geol. 2014;33:280-5 (in Chinese).

Liu XX, Ding XQ, Zhang SN, et al. Origin and depositional model of deep-water lacustrine sandstone deposits in the 7th and 6th members of the Yanchang Formation (Late Triassic), Binchang area, Ordos Basin, China. Pet Sci. 2017;. doi:10.1007/s12182016-0146-x.

Pan S, Wei P, Wang T, et al. Mass-transport deposits of the upper cretaceous Qingshankou Formation, Songliao Terrestrial Basin, Northeast China: depositional characteristics, recognition criteria and external geometry. Acta Geol Sin (English Ed). 2014;88(1):62-77. doi:10.1111/1755-6724.12183.

Pang X, Li S, Jin Z, et al. Quantitative assessment of hydrocarbon expulsion of petroleum systems in the Niuzhuang sag, Bohai Bay Basin, East China. Acta Geol Sin (English Ed). 2004;78(3):615-25. doi:10.1111/j.1755-6724.2004.tb00174.x.

Passey QR, Bohacs K, Esch WL, et al. From oil-prone source rock to gas-producing shale reservoir-geologic and petrophysical characterization of unconventional shale gas reservoirs. In International oil and gas conference and exhibition in China 2010 Jan 1. Society of Petroleum Engineers. Beijing, China; 2010.

Raji M, Gröcke DR, Greenwell HC, et al. The effect of interbedding on shale reservoir properties. Mar Pet Geol. 2015;67:154-69. doi:10.1016/j.marpetgeo.2015.04.015.

Ran XQ, Zhu XM, Yang H, et al. Petroleum enrichment theory and practice for low permeability reservoir in large continental basin. Earth Sci Front. 2013;20:147-54.

Schlische RW. Progress in understanding the structural geology, basin evolution, and tectonic history of the eastern North American rift system. In: LeTourneau PM, Olsen PE, editors. Aspects of Triassic-Jurassic Rift Basin Geoscience. New York: Columbia University Press; 2003. p. 21-54.

Schmoker JW. Method for assessing continuous-type (unconventional) hydrocarbon accumulations. In: Gautier DL, Dolton GL, Takahashi KI, et al. editors. National assessment of United States oil and gas resources-Results, methodology, and supporting data. U.S. Geological Survey Digital Data Series. DDS-30; 1995.

Sonnenberg SA. The Niobrara petroleum system: a new resource play in the Rocky Mountain region. In: Estes-Jackson JE, Anderson DS, editors. Revisiting and Revitalizing the Niobrara in the Central Rockies, Rocky Mountain Association of Geologists, Denver, Colorado; 2011, pp. 12-32.

Sonnenberg SA. The upper Bakken Shale resource play, Williston Basin. URTeC:1918895, In: Unconventional resources technology conference, 25-27 August; 2014. Denver, Colorado.

Wang HZ, Mo XX. An outline of the tectonic evolution of China. Episodes. 1995;18:6-16.

Wang $\mathrm{H}$, Li S. Tectonic evolution of China and its control over oil basins. J China Univ Geosci. 2004;15(1):1-8.
Wang H, Zhang SH, He GQ. China and mongolia. In: Selley RC, Cocks LRM, Plimer IR, editors. Encyclopedia of geology. Amsterdam: Elsevier; 2005. p. 345-58.

Wang H, Ma F, Wang Z, et al. Hydrocarbon plays and unconventional hydrocarbon distribution in lacustrine basin, China.URTeC:1921691. In: Unconventional resources technology conference (URTeC), 25-27 August, 2014. Denver, Colorado.

Xiang B, Zhou N, Ma W, et al. Multiple-stage migration and accumulation of Permian lacustrine mixed oils in the central Junggar Basin (NW China). Mar Pet Geol. 2015;59:187-201. doi:10.1016/j.marpetgeo.2014.08.014.

$\mathrm{Xu}$ SL, Bao SJ. Preliminary analysis of shale gas resource potential and favorable areas in Ordos Basin. Nat Gas Geosci. 2009;20(3):460-65 (in Chinese).

Yang Y, Li W, Ma L. Tectonic and stratigraphic controls of hydrocarbon systems in the Ordos basin: a multicycle cratonic basin in central China. AAPG Bull. 2005;89(2):255-69. doi:10. 1306/10070404027.

Yang H, Li S, Liu X. Characteristics and resource prospects of tight oil and shale oil in Ordos Basin. Acta Pet Sin. 2013;34(1):1-11. doi:10.7623/syxb201301001.

Yang T, Cao YC, Wang YZ, et al. The coupling of dynamics and permeability in the hydrocarbon accumulation period controls the oil-bearing potential of low permeability reservoirs: a case study of the low permeability turbidite reservoirs in the middle part of the third member of Shahejie Formation in Dongying Sag. Pet Sci. 2016;13(2):204-24. doi:10.1007/s12182-016-0099-0.

Yao J, Deng X, Zhao Y, et al. Characteristics of tight oil in Triassic Yanchang Formation, Ordos Basin. Pet Explor Dev. 2013;40(2):161-9. doi:10.1016/S1876-3804(13)60019-1.

Zeng $\mathrm{L}, \mathrm{Li} \mathrm{X}$. Fractures in sandstone reservoirs with ultra-low permeability: a case study of the Upper Triassic Yanchang Formation in the Ordos Basin, China. AAPG Bull. 2009;93(4):461-77. doi:10.1306/09240808047.

Zhang J, Xu B, Nie H, et al. Exploration potential of shale gas resources in China. Nat Gas Ind. 2008a;28(6):136-40.

Zhang LY, Li Z, Zhu RF, et al. Resource potential of shale gas in the Paleogene in the Jiyang depression. Nat Gas Ind. 2008b;12:009.

Zhang D, Li Y, Zhang J, et al. National survey and assessment of shale gas resource potential in China. Beijing: Geologic Publishing House; 2012a (in Chinese).

Zhang S, Zhang L, Li Z, et al. Formation conditions of Paleogene shale oil and gas in Jiyang depression. Pet Geol Recov Effic. 2012b;19(6):1-5 (in Chinese).

Zhang NN, Liu LF, Su TX, et al. Comparison of Chang 7 member of Yanchang Formation in Ordos Basin with Bakken Formation in Williston Basin and its significance. Geoscience. 2013;27(5):1120-30 (in Chinese).

Zhang L, Li J, Li Z, et al. Advancements in shale oil/gas research in North America and considerations on exploration for lacustrine shale oil/gas in China. Adv Earth Sci. 2014;29(6):700-11. doi:10.11867/j.issn.1001-8166.2014.06.0700 (in Chinese).

Zhang XS, Wang HJ, Ma F, et al. Classification and characteristics of tight oil plays. Pet Sci. 2016;13(1):18-33. doi:10.1007/s12182015-0075-0.

Zhou Z, Mu L, Li X, et al. Hybrid fracturing treatments unleash tight oil reservoirs consisting of sand/shale sequences in the Changqing Oilfield. In: IADC/SPE Asia Pacific drilling technology conference and exhibition 2012 Jan 1. Society of Petroleum Engineers. IADC/SPE Asia Pacific Drilling Technology Conference and Exhibition. 9-11 July; 2012. Tianjin, China.

Zhu G, Jin Q, Zhang S, et al. Combination characteristics of lake facies source rock in the Shahejie Formation, Dongying Depression. Acta Geol Sin. 2004;78(3):416-27 (in Chinese). 
Zou CN, Dong D, Wang S, et al. Geological characteristics and resource potential of shale gas in China. Pet Explor Dev. 2010;37(6):641-53. doi:10.1016/S1876-3804(11)60001-3.

Zou CN, Wang L, Li Y, et al. Deep-lacustrine transformation of sandy debrites into turbidites, Upper Triassic, Central China. Sedim Geol. 2012;265:143-55. doi:10.1016/j.sedgeo.2012.04.004.

Zou CN, Tao S, Hou L, et al. Unconventional petroleum geology. 2nd ed. Beijing: Geological Publishing; 2013a.

Zou CN, Yang Z, Cui J, et al. Formation mechanism, geological characteristics and development strategy of nonmarine shale oil in China. Pet Explor Dev. 2013b;40(1):15-27. doi:10.1016/ S1876-3804(13)60002-6.

Zou CN, Yang Z, Zhang G, et al. Conventional and unconventional petroleum "orderly accumulation": concept and practical significance. Pet Explor Dev. 2014;41(1):14-30. doi:10.1016/ S1876-3804(14)60002-1.

Zou CN, Yang Z, Hou LH, et al. Geological characteristics and "sweet area" evaluation for tight oil. Pet Sci. 2015;12(4):606-17. doi:10. 1007/s12182-015-0058-1. 